\title{
Altered Neuron Excitability and Synaptic Plasticity in the Cerebellar Granular Layer of Juvenile Prion Protein Knock- Out Mice with Impaired Motor Control
}

\author{
Francesca Prestori, ${ }^{1}$ Paola Rossi, ${ }^{1}$ Bertrand Bearzatto, ${ }^{3}$ Jeanne Lainé, ${ }^{4}$ Daniela Necchi, ${ }^{2}$ Shyam Diwakar, ${ }^{1}$ \\ Serge N. Schiffmann, ${ }^{3}$ Herbert Axelrad, ${ }^{4}$ and Egidio D'Angelo ${ }^{1}$ \\ ${ }^{1}$ Department of Molecular/Cellular Physiology and Consorzio Nazionale Interuniversitario per le Scienze Fisiche della Materia, and ${ }^{2}$ Department of Animal \\ Biology, University of Pavia, 27100 Pavia, Italy, ${ }^{3}$ Laboratoire de Neurophysiologie (CP601), Faculté de Médecine, Université Libre de Bruxelles, B-1070 \\ Bruxelles, Belgium, and ${ }^{4}$ Laboratory of Cerebellar Neurobiology, Faculté de Médecine Pitiê-Salpétrière, 75013 Paris, France
}

\begin{abstract}
Although the role of abnormal prion protein ( $\mathrm{PrP}$ ) conformation in generating infectious brain diseases (transmissible spongiform encephalopathy) has been recognized, the function of $\operatorname{PrP}$ in the normal brain remains mostly unknown. In this investigation, we considered the effect of PrP gene knock-out $\left(\mathrm{PrP}^{0 / 0}\right)$ on cerebellar neural circuits and in particular on granule cells, which show intense PrP expression during development and selective affinity for PrP. At the third postnatal week, when PrP expression would normally attain mature levels, $\mathrm{PrP}^{0 / 0}$ mice showed low performance in the accelerating rotarod and runway tests and the functioning of $40 \%$ of granule cells was abnormal. Spikes were slow, nonovershooting, and nonrepetitive in relation with a reduction in transient inward and outward membrane currents, and also the EPSPs and EPSCs had slow kinetics. Overall, these alterations closely resembled an immature phenotype. Moreover, in slow-spiking $\mathrm{PrP}^{0 / 0}$ granule cells, theta-burst stimulation was unable to induce any long-term potentiation. This profound impairment in synaptic excitation and plasticity was associated with a protracted proliferation of granule cells and disappeared at P40-P50 along with the recovery of normal motor behavior (Büeler et al., 1992). These results suggest that PrP plays an important role in granule cell development eventually regulating cerebellar network formation and motor control.
\end{abstract}

Key words: cerebellum; granule cell; prion; LTP; action potential; motor control

\section{Introduction}

The prion protein $(\mathrm{PrP})$ is a cell surface protein, whose abnormal conformation leads to transmissible spongiform encephalopathy (TSE), including "mad cow" disease in bovines, scrapie in sheep, and Creutzfeldt-Jakob disease in humans (Prusiner, 1998; Harris and True, 2006). Brain alterations consist in vacuolization of neurons and synapses associated with $\operatorname{PrP}$ accumulation in polymeric aggregates. Prion infection causes a slowly progressive neurodegeneration impairing higher brain functions and motor control.

In face of the wealth of evidence on pathogenetic mechanisms, PrP physiological functions remain unclear. A first investigation on PrP knock-out mice ( $\mathrm{PrP}^{0 / 0}$ ) (Büeler et al., 1992) did not reveal macroscopic developmental and behavioral alterations. However, subsequent analysis revealed several motor, cognitive, and emotional abnormalities (Roesler et al., 1999; Criado et al., 2005) and increased susceptibility to seizures (Walz et al., 2002). Recordings from brain slices of $\mathrm{PrP}^{0 / 0}$ mice showed reduced syn-

\footnotetext{
Received Feb. 24, 2007; revised May 20, 2008; accepted June 3, 2008.

This work was supported by European Community Grants PL97-6060 "Cerebellar Network Alterations in Prion Diseases" and SENSOPAC FP6-IST028056. We thank Paola Lombardo for surgery in the immunolabeling experiments.

Correspondence should be addressed to Egidio D'Angelo at the above address. E-mail: dangelo@unipv.it. DOI:10.1523/JNEUROSCI.0409-08.2008

Copyright $\odot 2008$ Society for Neuroscience $\quad$ 0270-6474/08/287091-13\$15.00/0
}

aptic inhibition and long-term potentiation (LTP) (a neural correlate of learning) (Bliss and Collingridge, 1993) in the hippocampus (Collinge et al., 1994; Curtis et al., 2003; Maglio et al., 2004, 2006), but this observation was not confirmed (Lledo et al., 1996).

Several abnormalities have been observed in $\mathrm{PrP}^{0 / 0}$ neurons in culture, including reduced $\mathrm{Ca}^{2+}$-dependent $\mathrm{K}^{+}$currents (Colling et al., 1996; Herms et al., 2001; Mallucci et al., 2002) and cytoplasmic $\mathrm{Ca}^{2+}$ levels (Herms et al., 2000). PrP is distributed on the neuron surface and in presynaptic terminals (Herms et al., 1999; Ferrer et al., 2000). Despite initial negative observations, there is now growing evidence that PrP regulates neuronal survival and differentiation (Steele et al., 2006) through its interaction with laminin and intracellular signaling cascades (Graner et al., 2000). In keeping with this, PrP expression is highly regulated during ontogenesis and by nerve growth factor, and susceptibility to prion diseases is maximal during development (Manson et al., 1992; Martins et al., 2002).

Although multiple structures of the CNS (including neocortex, thalamus, hippocampus, and cerebellum) are affected, $\operatorname{PrP}$ physiopathology is significantly related to the cerebellum and cerebellar ataxia appears to be one of the main clinical signs in a number of TSEs (Prusiner, 1998). Binding of prion protein to cerebellar granule cells may have a distinct role in the pathogenetic mechanism (Shmerling et al., 1998; Legname et al., 2002). 
PrP is expressed in the cerebellum granular layer (Lainé et al., 2001) showing a characteristic developmental profile, with a steep increase during the second postnatal week (Salès et al., 2002). Interestingly, PrP expression parallels the major ontogenetic changes characterizing the mossy fiber-granule cell relay (Altman, 1972; Hámori and Somogyi, 1983; D’Angelo et al., 1993, 1994, 1997; Farrant et al., 1994; Rossi et al., 1994, 1998, 2002; Rumbaugh and Vicini, 1999; Cathala et al., 2000, 2003; Wall et al., 2002) and goes along with a marked improvement of supporting sensorimotor reactions (Altman and Sudarshan, 1975).

In this study, we investigated the effect of PrP knock-out at the cerebellar mossy fiber-granule cell relay (Eccles et al., 1967) in juvenile $\operatorname{PrP}^{0 / 0}$ mice. $\operatorname{PrP}^{0 / 0}$ mice showed low performance in sensorimotor tests. At the same time, a large proportion of granule cells showed an immature electroresponsive phenotype and their synapses lacked long-term potentiation (D'Angelo et al., 1999; Armano et al., 2000; Hansel et al., 2001; Rossi et al., 2002). These alterations were associated with an abnormal duplication of granule cells in the germinal zone of the external granular layer (EGL) during the third postnatal week but fully recovered in the adulthood, suggesting an important role of PrP for cerebellar network formation and motor control during development.

\section{Materials and Methods}

Experimental animals

The prion protein knock-out $\left(\mathrm{PrP}^{0 / 0}\right)$ mice were of the "Zurich-I" strain developed by Büeler et al. (1992). The wild-type mice (C57 × Sv129) were descendents of $\mathrm{F}_{2}$ generation mouse produced by interbreeding the parental strain (C57BL/6J and 129S1/SvImJ mice; The Jackson Laboratory) used to generate $\mathrm{PrP}^{0 / 0}$ mice. Controls were reinforced by using C57BL/6J, which is the most common inbred strain used for experimental electrophysiology. Most experiments were performed on juvenile mice [postnatal day 17 (P17) to P22; day of birth, P0], when granule cells have just attained mature structural (Altman, 1972; Hámori and Somogyi, 1983), excitable, and synaptic properties (D’Angelo et al., 1993, 1994, 1997; Farrant et al., 1994; Rossi et al., 1994, 1998, 2002; Rumbaugh and Vicini, 1999; Cathala et al., 2000, 2003; Wall et al., 2002) and controls have also been performed at different ages.

\section{Electrophysiological recordings}

All experiments were performed according to the guidelines laid down by the institution's animal welfare committee. We performed whole-cell patch-clamp recordings from granule cells in acute cerebellar as reported previously (D’Angelo et al., 1999) from P17-P22 mice. Briefly, mice were killed by decapitation after anesthesia with halothane $(1 \mathrm{ml}$ in $2 \mathrm{~L}$ administered for 1-2 $\mathrm{min}$ ). The cerebellum was gently removed, and the vermis was isolated and fixed on the stage of a vibroslicer (Dosaka) with cyanoacrylic glue. Acute $250-\mu \mathrm{m}$-thick slices were cut in the parasagittal plane in cold Kreb's solution and maintained at room temperature before being transferred to a $1.5 \mathrm{ml}$ recording chamber mounted on the stage of un upright microscope (Olympus). The slices were perfused with Kreb's solution and maintained at $32^{\circ} \mathrm{C}$ with a Peltier feedback device (HCC100A; Dagan Corporation). The Kreb's solution contained the following (in mM): $120 \mathrm{NaCl}, 2 \mathrm{KCl}, 1.2 \mathrm{MgSO}_{4}, 26 \mathrm{NaHCO}_{3}, 1.2 \mathrm{KH}_{2} \mathrm{PO}_{4}, 2 \mathrm{CaCl}_{2}$, and 11 glucose, and was equilibrated with $95 \% \mathrm{O}_{2}$ and $5 \% \mathrm{CO}_{2}$, for $\mathrm{pH}$ 7.4. For recordings, Kreb's solution was added with the $\mathrm{GABA}_{\mathrm{A}}$ receptor antagonist bicuculline $(10 \mu \mathrm{M})$ (Tocris Bioscience). Local perfusion with Kreb's solution and $10 \mu \mathrm{M}$ bicuculline was commenced before seal formation and was maintained until end of recording. For P40-P50 slices, Kreb's solution for cutting and recovery was modified as reported by Goldfarb et al. (2007) to improve tissue viability.

Recordings were performed with an Axopatch 200-B amplifier [-3
$\mathrm{dB}$; cutoff frequency $\left(f_{\mathrm{c}}\right), 10 \mathrm{kHz}$, sampled with Digidata 1200 interface, and analyzed off-line with pClamp software (Molecular Devices). Patch pipettes were pulled from borosilicate glass capillaries (Hilgenberg) and filled with different solutions depending on the specific experiments (see below). Mossy fiber stimulation was performed with a bipolar tungsten electrode (Clark Instruments) via a stimulus isolation unit. The stimulating electrode was placed over the central fiber bundle in the cerebellar lamina to stimulate the mossy fibers, and $200 \mu$ s step current pulses were applied at the frequency of $0.1-0.33 \mathrm{~Hz}$. For LTP induction we used theta-burst stimulation (TBS) (four $100 \mathrm{~ms}, 100 \mathrm{~Hz}$ bursts of impulses repeated every $250 \mathrm{~ms}$ ), as reported previously (D'Angelo et al., 1999; Armano et al., 2000; Rossi et al., 2002). Results are reported as mean \pm SEM and compared for their statistical significance by unpaired Student's $t$ test (a difference was considered significant at $p<0.05$ ).

Whole-cell recording properties. The cerebellar granule cell is electrotonically compact and can be treated as a simple RC system, in which relevant parameters can be extracted by analyzing passive current relaxation induced by step voltage changes. In each recording, once in the whole-cell configuration, the current transients elicited by $10 \mathrm{mV}$ hyperpolarizing pulses from the holding potential of $-70 \mathrm{mV}$ in voltage-clamp mode showed a biexponential relaxation, with a major component $(\sim 95 \%)$ related to somatodendritic charging (see supplemental material, available at www.jneurosci.org). According to previous reports (D'Angelo et al., 1995, 1999; Silver et al., 1996), the major component was analyzed to extract basic parameters useful to evaluate the recording conditions and to compare different cell groups. Membrane capacitance $\left(C_{\mathrm{m}}\right)$ was measured from the capacitive charge (the area underlying current transients) and series resistance $\left(R_{\mathrm{s}}\right)$ was calculated as $R_{\mathrm{s}}=\tau_{\mathrm{VC}} / C_{\mathrm{m}}$. The membrane resistance $\left(R_{\mathrm{m}}\right)$ was computed from the steady-state current flowing after termination of the transient. The $-3 \mathrm{~dB}$ cutoff frequency of the electrode-cell system, $f_{\mathrm{VC}}$, was calculated as $f_{\mathrm{VC}}=$ $\left(2 \pi \tau_{\mathrm{VC}}\right)^{-1}$. The data are reported in Table 1. The electrotonic properties were further analyzed and simulated using a multicompartmental model, as explained in the supplemental material (available at www.jneurosci.org).

Granule cell excitability. Patch pipettes had of 8-12 $\mathrm{M} \Omega$ resistance before seal formation with a filling solution containing the following (in $\mathrm{mm}$ ): $126 \mathrm{~K}$-gluconate, $4 \mathrm{NaCl}, 5 \mathrm{HEPES}, 15$ glucose, $1 \mathrm{MgSO}_{4} \cdot 7 \mathrm{H}_{2} \mathrm{O}, 0.1$ BAPTA-free and 0.05 BAPTA-Ca ${ }^{2+}, 3 \mathrm{Mg}$-ATP, $\mathrm{pH}$ adjusted to 7.2 with $\mathrm{KOH}$. Just after obtaining the cell-attached configuration, electrode capacitance was carefully cancelled to allow for electronic compensation of pipette charging during subsequent current-clamp recordings, and the amplifier was set to the "fast" operating mode (D'Angelo et al., 1995, 1998). At the beginning of each recording, passive transients were elicited to monitor passive cell properties (see below) and a series of depolarizing steps was applied in voltage clamp to measure the total voltagedependent current of the granule cell (see Fig. 2). Leakage and capacitive currents were subtracted using hyperpolarizing pulses delivered before the test pulse ( $\mathrm{P} / 4$ protocol). After switching to current clamp, intrinsic excitability was investigated (see Fig. 4) by setting resting membrane potential at $-80 \mathrm{mV}$ and injecting $2 \mathrm{~s}$ or $800 \mathrm{~ms}$ steps of current (from -8 to $48 \mathrm{pA}$ in a 2 or $4 \mathrm{pA}$ increment).

Membrane potential during $2 \mathrm{~s}$ step current was estimated as the average value between 1.7 and $2 \mathrm{~s}$, whereas membrane potential during 800 ms step current was estimated as the average value between 500 and 800 
ms. Membrane potential during TBS was estimated as the mean of average values measured in the central $70 \mathrm{~ms}$ of each burst (tracings were filtered at $100 \mathrm{~Hz}$ ). Action potentials in granule cells show a prepotential followed by the upstroke (D’Angelo et al., 1997; Armano et al., 2000). Action potential threshold was measured along the raising phase of membrane potential responses to step current injection. The prepotential threshold was identified at the flexus starting the regenerative process (a procedure that was improved by taking the first time derivative of membrane potential), whereas the upstroke threshold was identified by taking the second time derivative of the signal. Spike duration at halfamplitude was evaluated using the first spike generated with justthreshold current stimulation and measured at the midpoint between the threshold of spike upstroke and peak. The amplitude of the action potential overshoot was estimated as the difference between the threshold of spike upstroke and the maximum reached potential. The amplitude of the action potential afterhyperpolarization (AHP) was estimated as the difference between spike threshold and the lowest potential after the upstroke. Action potential frequency was measured by dividing the number of spikes by the current injected duration.

In a specific set of recordings, synaptic responses were elicited at $0.1-$ $0.33 \mathrm{~Hz}$ to activate the mossy bundle while measuring EPSPs from a resting membrane potential of $-70 \mathrm{mV}$. EPSPs were averaged and analyzed off-line to measure peak amplitude and decay time constant through a simple exponential fitting. LTP was induced by TBS delivered $10 \mathrm{~min}$ after establishing the whole-cell recording configuration (time $=$ 0 ) from the membrane potential of $-50 \mathrm{mV}$. In LTP recordings in current clamp, stability was monitored by measuring the resting membrane potential and the input resistance in a low membrane potential range (less than $-70 \mathrm{mV}$ ).

Synaptic currents. Patch pipettes had 5-8 $\mathrm{M} \Omega$ resistance before seal formation with a filling solution containing the following (in $\mathrm{mM}$ ): 81 $\mathrm{Cs}_{2} \mathrm{SO}_{4}, 4 \mathrm{NaCl}, 2 \mathrm{MgSO}_{4}, 1 \mathrm{QX}-314$ (lidocaine $\mathrm{N}$-ethyl bromide), 0.1 BAPTA-free and 0.05 BAPTA-Ca ${ }^{2+}, 15$ glucose, $3 \mathrm{Mg}$-ATP, $0.1 \mathrm{GTP}$, and 15 HEPES, $\mathrm{pH}$ adjusted to 7.2 with $\mathrm{CsOH}$. The EPSCs were elicited at $0.33-0.1 \mathrm{~Hz}$ by interleaving periods at $+60 \mathrm{mV}$ and at $-70 \mathrm{mV}$ to modify the NMDA/AMPA current ratio. EPSCs were averaged and digitally filtered at $1.5 \mathrm{kHz}$ off-line. EPSC peak amplitude and EPSC amplitude 25 $\mathrm{ms}$ after stimulation were taken at -70 and $+60 \mathrm{mV}$ to measure the non-NMDA and NMDA currents, respectively. The decay phases of EPSCs at either potentials were fitted with double exponentials of the following form by a nonlinear least-squares method using pClamp software (Molecular Devices): $A(t)=A_{1} \exp \left(-t / \tau_{1}\right)+A_{2} \exp \left(-t / \tau_{2}\right)$, where $A(t)$ is the amplitude of the decay phase of the EPSC or EPSP as a function of time $(t), A_{1}$ and $A_{2}$ are the amplitudes of the fast and slow decay components, and $\tau_{1}$ and $\tau_{2}$ are their respective decay time constants. For a single exponential decay, $A_{2}$ was set to zero. The weighted decay time constant (Rumbaugh and Vicini, 1999) was estimated as follows: $\tau_{w}=\tau_{1} \times\left[A_{1} /\right.$ $\left.\left(A_{1}+A_{2}\right)\right]+\tau_{2} \times\left[A_{2} /\left(A_{1}+A_{2}\right)\right]$. Fittings were performed from peak at $-70 \mathrm{mV}$ and from $25 \mathrm{~ms}$ after the stimulus at $+60 \mathrm{mV}$.

In some experiments, after a $10 \mathrm{~min}$ control period, LTP was induced by TBS while stepping membrane potential from -70 to $-30 \mathrm{mV}$. In LTP recordings in voltage clamp, $R_{\mathrm{s}}$ stability was monitored throughout the experiment.

\section{Behavioral tests}

The behavioral analysis was performed on naive, juvenile $\operatorname{PrP}^{0 / 0}$ and wild-type $(\mathrm{C} 57 \times$ Sv129) mice. At the first day of the test the animals were P19. The animals were housed in groups of three to four in clear plastic cages maintained in a temperature- and humidity-controlled room on a $12 \mathrm{~h}$ light/dark schedule with food and water provided ad libitum. All experiments were conducted in the light phase of circadian cycle between 9:00 A.M. and 4:00 P.M. Every day, animals were sequentially subjected to the runway and accelerating rotarod test. The study was approved by the Institutional Ethical Committee of the School of Medicine, Université Libre de Bruxelles, Belgium.

In the runway test, mice had to run along an elevated runway with low obstacles intended to impede their progress. The runway was $100 \mathrm{~cm}$ long and $0.7 \mathrm{~cm}$ wide, and obstacles of $1 \mathrm{~cm}$ diameter were placed every $10 \mathrm{~cm}$ along the runway. Mice were placed on one brightly illuminated
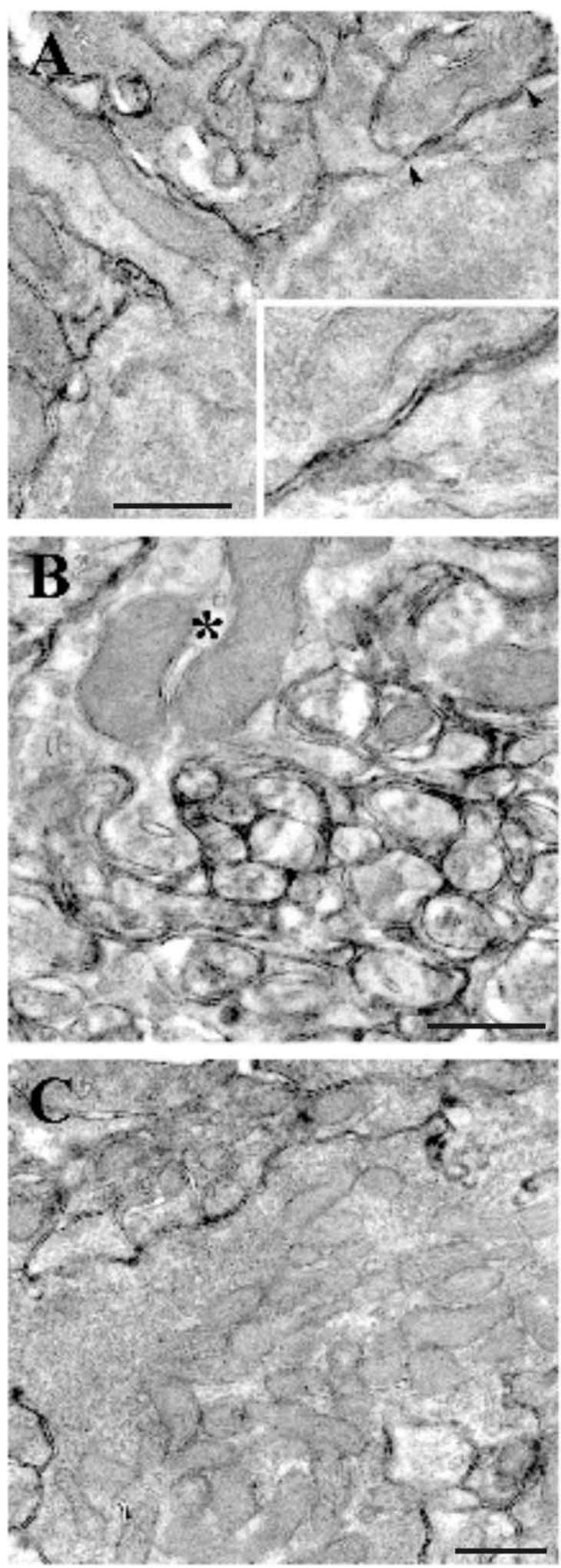

Figure 1. PrP labeling in mouse cerebellum. At P20, PrP is expressed on all glomerular structures. $\boldsymbol{A}$, High-magnification micrograph of a portion of granule cell soma with an emerging dendrite whose outer plasmalemma is covered with immunoprecipitate. The enlarged membrane portion (delimited by arrowheads) shown in the inset clearly exhibits a punctate PrP labeling. The latter is present both on the granule cell somatic outer membrane and on the membrane of a juxtaposed axonal profile. $\boldsymbol{B}$, Transversally cut parallel fibers in the molecular layer: PrP is densely present on the axolemma of granule cell axons. An interneuronal dendritic profile is also PrP labeled (asterisk). C, Mossy fiber rosette in the granular layer. The outer plasmalemma exhibits punctate precipitate, but, as is the case in the adult cerebellum, no labeling is present within the axoplasm nor on the axonal vesicles. Scale bars, $500 \mathrm{~nm}$. 
extremity of the runway and had to run to the other side where they retrieved their cage. The number of slips of the right hindlegs was counted. Animals were given four trials per day during 5 consecutive days. The rotarod apparatus (accelerating model; Ugo Basile) consisted of a plastic roller ( $3 \mathrm{~cm}$ in diameter) with small grooves running along its turning axis. On the first day, mice were given a training session. During this training session, every mouse was placed on the rotarod at a constant speed (4 $\mathrm{rpm}$ ) for a maximum of $60 \mathrm{~s}$. Afterward, mice received four trials per day during 7 consecutive days. During each test session, animals were placed on the rod rotating at a constant speed (4 $\mathrm{rpm})$. As soon as the animals were placed on the rod, the rod started to accelerate continuously from 4 to $40 \mathrm{rpm}$ over $300 \mathrm{~s}$. The latency to fall off the rotarod was recorded. Animals staying during $300 \mathrm{~s}$ were taken from the rotarod and recorded as $300 \mathrm{~s}$.

Strains were compared using a two-way ANOVA and Bonferroni's post hoc test. Results are expressed as mean \pm SEM and were considered significant if $p<0.05$.

\section{Morphological techniques}

Immunoelectron microscopy. P20 C57 × Sv129 mice were deeply anesthetized (pentobarbital, $60 \mathrm{mg} / \mathrm{kg}$ ) and transcardially perfused with $4 \%$ paraformaldehyde plus $0.05 \%$ glutaraldehyde in cold $0.1 \mathrm{~m}$ phosphate buffer. The dissected cerebellum was further postfixed in $4 \%$ paraformaldehyde plus $15 \%$ sucrose for $2 \mathrm{~h}$ at $4^{\circ} \mathrm{C}$. Its vermal part was cut in $80-\mu \mathrm{m}$-thick parasagittal sections with a vibratome. Sections were then cryoprotected and permeabilized by freezethawing. Preembedding was performed with a standard free-floating immunocytochemical procedure using $0.1 \mathrm{M}$ saline phosphate buffer as diluent and rinsing liquids, without any adjunction of detergent. Briefly, aldehyde quenching in $0.1 \mathrm{M}$ glycine was followed by preincubation in $10 \%$ normal horse serum and overnight incubation at $4^{\circ}$ in SAF 32, a monoclonal antibody directed against the $\mathrm{N}$-terminal region of $\mathrm{PrP}$ and characterized as recognizing the human octarepeat sequence 52-92 (Demart et al., 1999). After incubation in $1 / 200$ biotinylated horse anti-mouse IgG (Vector Laboratories), a standard avidin-biotin complex revelation (Vectastain Elite; Vector Laboratories) was applied, using $0.05 \%$ diaminobenzidine as the chromagen. For electron microscopy (EM), after $2 \%$ $\mathrm{OsO} 4$ postfixation and $2 \%$ uranyl acetate en bloc staining, selected sections were dehydrated in graded acetone and finally embedded in Durcupan (Fluka) resin. Un-counterstained ultrathin sections were examined with a Philips CM100 electron microscope, operated at $60 \mathrm{kV}$.

5-Bromodeoxyuridine immunostaining. At different postnatal days (8, $12,15,20,25,40), \mathrm{PrP}^{0 / 0}$ and control $\mathrm{C} 57 \mathrm{BL} / 6 \mathrm{~J}$ mice were injected intraperitoneally with 5-bromodeoxyuridine (BrdU) (Sigma-Aldrich) (50 $\mu \mathrm{g} / \mathrm{g}$ body weight) dissolved in ethanol 25\% in PBS. Three hours after treatment, animals were killed by decapitation, and brains were excised and placed into Carnoy's fixative (ethanol absolute/chloroform/acetic acid, 6:3:1) overnight. Subsequently, brains were dehydrated through a series of graded ethanols and embedded in Paraplast X-tra. Sagittal 10 $\mu \mathrm{m}$ sections were cut and mounted onto gelatin-coated slides. The slides

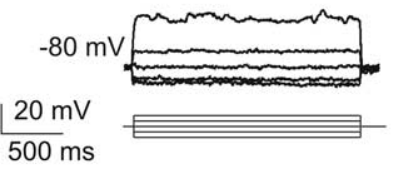

B

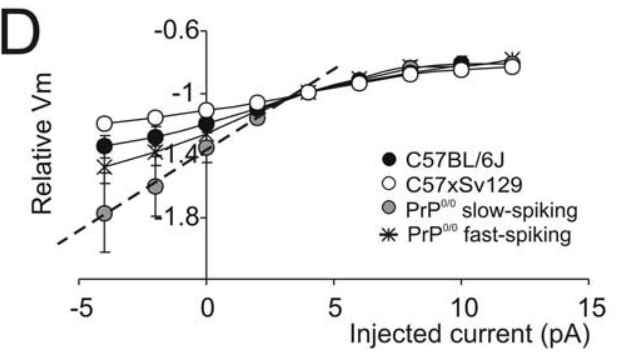

C57BL/6J

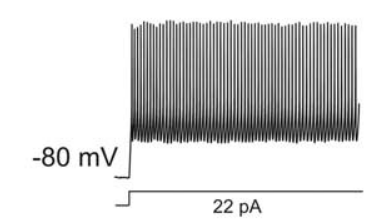

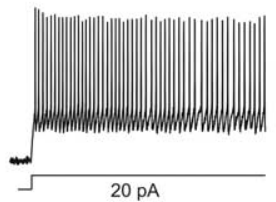

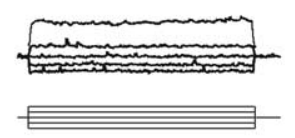

C57xSv129
$\operatorname{PrP}^{0 / 0}$ fast-spiking
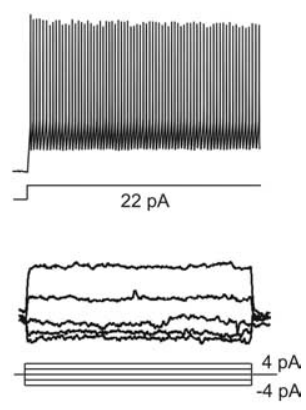

Figure 2. Granule cell electroresponsiveness. Voltage responses were elicited from $-80 \mathrm{mV}$ using step current injection (intensities are indicated below tracings) in wild-type and $\operatorname{PrP}{ }^{0 / 0}$ mice. $\boldsymbol{A}$, Examples of $\left(57 \times \mathrm{Sv} 129,\left(57 \mathrm{BL} / 6 \mathrm{~J}\right.\right.$, and $\operatorname{PrP} \mathrm{P}^{0 / 0}$ granule cells generating fast repetitive spike discharge. Note also the fast inward rectification in the subthreshold voltage response. $\boldsymbol{B}$, A slow-spiking $\mathrm{PrP}^{0 / 0}$ granule cell generates a broad nonrepetitive action potential and shows no inward rectification. C, Threshold-aligned wild-type and $\mathrm{PrP}^{0 / 0}$ action potentials. Note smaller spike overshoot, smaller AHP, and greater halfwidth in the slow-spiking $\mathrm{PrP}^{0 / 0}$ granule cell. D, Subthreshold steady-state depolarization (left) and discharge frequency (right) in the different groups of granule cells. In the plot at the left, relative membrane potentials were calculated by dividing the actual values by $-70 \mathrm{mV}$. The straight dashed line interpolates the points more negative than $-70 \mathrm{mV}$ in slow-spiking PrP ${ }^{0 / 0}$ granule cells, evidencing the absence of inward rectification, which conversely characterizes the other three cell groups. In the plot at the right, note that slow-spiking PrP ${ }^{0 / 0}$ granule cells have very low frequency of discharge on current injection (in the case that only one spike was observed, the frequency was set to 0). Data are mean \pm SEM (C57BL/6J, $n=22 ;\left(57 \times\right.$ Sv129, $n=23 ; \mathrm{PrP}^{0 / 0} \mathrm{fast}$, $n=12 ; \mathrm{PrP}^{0 / 0}$ slow, $n=8$ ). Note in the inset that slow-spiking PrP ${ }^{0 / 0}$ granule cells were evenly distributed in the P17-P22 age window used for the present recordings (gray, slow-spiking $\mathrm{PrP}^{0 / 0}$; hatched, fast-spiking $\mathrm{PrP}^{0 / 0}$ ).

were deparaffinized in xylene, rehydrated, and processed for immunohistochemistry for BrdU. Sections were treated with proteinase K (20 $\mu \mathrm{g} / \mathrm{ml}$; Sigma-Aldrich) for $7 \mathrm{~min}$ at room temperature and then with $2 \mathrm{~N}$ $\mathrm{HCl}$ in $0.1 \mathrm{M} \mathrm{PBS}$ for $45 \mathrm{~min}$ to enhance binding of the primary antibody. After that, sections were incubated in $3 \% \mathrm{H}_{2} \mathrm{O}_{2}$ in $10 \%$ methanol in $0.1 \mathrm{M}$ PBS for $7 \mathrm{~min}$, to block endogenous peroxidase, and then sections were exposed to $5 \%$ nonfat milk in 0.1 м PBS containing $0.5 \%$ Triton X-100 and $0.1 \% \mathrm{NaN}_{3}$. Thereafter, the sections were incubated overnight with an anti-BrdU antibody (clone B44; BD Biosciences) diluted 1:50 in $0.1 \mathrm{M}$ PBS containing $0.5 \%$ Triton $\mathrm{X}-100$ and $0.1 \% \mathrm{NaN}_{3}$. The primary antibody was detected by the biotin-streptavidin technique according to the procedure suggested by the supplier (Vectastain ABC Elite kit; Vector 
Table 2. Excitable properties

\begin{tabular}{|c|c|c|c|c|}
\hline & $(57 \mathrm{BL} / 6 \mathrm{~J}(n=22)$ & C57 $\times \operatorname{Sv} 129(n=23)$ & $\operatorname{PrP}^{0 / 0}$ fast $(n=12)$ & $\mathrm{PrP}^{0 / 0}$ slow $(n=8)$ \\
\hline$V_{\text {rest }}(\mathrm{mV})$ & $-60.7 \pm 2.8^{*}$ & $-60.5 \pm 2.5^{*}$ & $-52.3 \pm 8.3$ & $-47.0 \pm 5.0$ \\
\hline $\mathrm{AP}_{\mathrm{OS}}(\mathrm{mV})$ & $53.6 \pm 2.6^{* *}$ & $50.0 \pm 2.4^{* *}$ & $49.1 \pm 4.0^{* * *}$ & $29.0 \pm 2.6$ \\
\hline $\mathrm{AP}_{\mathrm{AHP}}(\mathrm{mV})$ & $19.8 \pm 1.8^{* * *}$ & $16.5 \pm 1.2^{* * *}$ & $18.4 \pm 1.2^{* * *}$ & $10.3 \pm 2.0$ \\
\hline \multirow[t]{2}{*}{$\mathrm{AP}_{\text {thr }}(\mathrm{mV})$} & $-42.7 \pm 2.0^{* * *}$ & $-48.3 \pm 1.2^{* *}$ & $-44.9 \pm 2.1^{* * *}$ & $-34.7 \pm 1.3$ \\
\hline & $\left(-36.0 \pm 2.2^{*}\right)$ & $\left(-36.6 \pm 0.7^{* * *}\right)$ & $\left(-36.1 \pm 1.8^{*}\right)$ & $(-29.1 \pm 1.8)$ \\
\hline $\mathrm{AP}_{\mathrm{HW}}(\mathrm{ms})$ & $1.2 \pm 0.15^{* * *}$ & $0.99 \pm 0.08^{* * *}$ & $1.4 \pm 0.2^{* * *}$ & $4.0 \pm 0.7$ \\
\hline $\mathrm{EPSP}_{\mathrm{ampl}}(\mathrm{mV})$ & $15.6 \pm 1.5$ & $14.9 \pm 1.3$ & $16.9 \pm 1.9$ & $15.8 \pm 3.1$ \\
\hline $\mathrm{EPSP}_{\tau}(\mathrm{ms})$ & $26.0 \pm 2.7^{* * *}$ & $30.5 \pm 3.6^{*}$ & $33.3 \pm 5.2^{*}$ & $49.9 \pm 9.3$ \\
\hline$I_{\text {in(peak) }}(\mathrm{pA} / \mathrm{pF})$ & $-309.8 \pm 27.7^{* *}$ & $-307.5 \pm 28.3^{* *}$ & $-232.9 \pm 37.4^{* * *}$ & $-83.3 \pm 12.3$ \\
\hline$I_{\text {in }(I / / \text { peak })}(\mathrm{mV})$ & $-26.5 \pm 2.3^{* * *}$ & $-27.9 \pm 1.9^{*}$ & $-27.5 \pm 1.5^{*}$ & $-12.5 \pm 3.6$ \\
\hline$I_{\text {out-t }(+20)}(\mathrm{pA} / \mathrm{pF})$ & $265.6 \pm 25.2^{* * *}$ & $244.5 \pm 14.3^{* *}$ & $238.2 \pm 23.4^{* * *}$ & $141.1 \pm 11.2$ \\
\hline$I_{\text {out }-\mathrm{p}(+20)}(\mathrm{pA} / \mathrm{pF})$ & $183.4 \pm 22.7^{* * *}$ & $170.8 \pm 13.9^{* * *}$ & $198.2 \pm 36.9^{*}$ & $107.5 \pm 10.8$ \\
\hline
\end{tabular}

The recorded granule cells had a slightly different resting membrane potential $\left(V_{\text {rest }}\right)$, which was then adjusted with constant current injection $(-70 \mathrm{mV}$ for EPSPs; $-80 \mathrm{mV} \mathrm{for} \mathrm{action} \mathrm{potentials})$ to normalize current-clamp recordings. The action potential overshoot $\left(\mathrm{AP}_{0 S}\right)$, duration at half-width $\left(\mathrm{AP}_{\mathrm{HW}}\right)$, and afterhyperpolarization ( $\left.\mathrm{AP}_{\mathrm{AHP}}\right)$ are calculated from threshold $\left(\mathrm{AP}_{\text {thr }}\right)$. The reported $\mathrm{AP}_{\text {thr }}$ corresponds to spike prepotential (the values in parentheses are the upstroke threshold). In the same cells, EPSP amplitude (EPSP $\left.{ }_{\text {ampl }}\right)$ and decay time constant $\left(\right.$ EPSP $\left._{\tau}\right)$ are indicated. The table also reports values for the maximum transient inward current $\left(l_{\text {in }}\right.$ (peak) $)$ along with the corresponding membrane potential $\left(I_{\text {in }(/ / V \text { peak })}\right)$, the transient outward current at $+20 \mathrm{mV}\left(I_{\text {out-t( }(+20)}\right)$, and the persistent outward current at $+20 \mathrm{mV}\left(I_{\text {out-p }(+20)}\right)$. The number of observations is indicated and statistical significance is reported in comparisons with slow-spiking $\mathrm{PrP}^{0 / 0}$ granule cells.

${ }^{*} p<0.05,{ }^{* *} p<0.001,{ }^{* * *} p<0.01$, unpaired $t$ test.

A

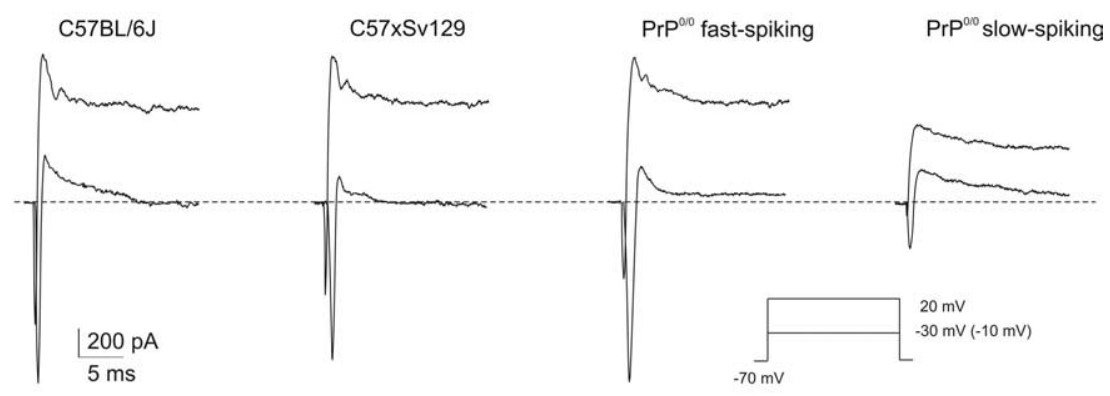

B

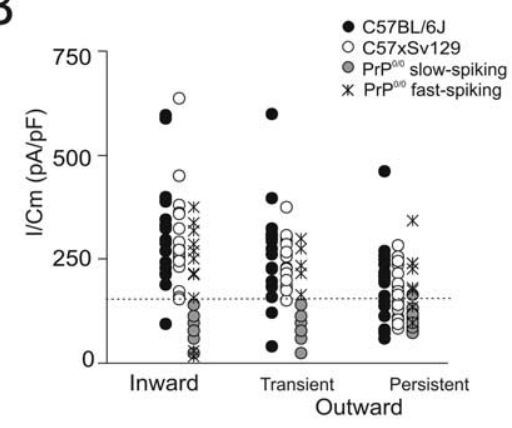

Figure 3. Voltage-activated inward and outward currents in granule cells. In slow-spiking PrP ${ }^{0 / 0}$ granule cells, the outward and inward currents are smaller than in wild-type granule cells. $A$, Voltage-dependent currents evoked by depolarizing voltage steps from the holding potential of $-70 \mathrm{mV}$. The inset shows the VC protocol (note that, to elicit inward currents in the $\mathrm{PrP}^{0 / 0}$ granule cells, a voltage command of $-10 \mathrm{mV}$ rather than $-30 \mathrm{mV}$ was needed). Traces were leak-subtracted (see Materials and Methods). $\boldsymbol{B}$, The scatter plot shows inward and outward current amplitudes measured at $-30 \mathrm{mV}$ (except for $-10 \mathrm{mV}$ in the slow-spiking granule cell) and $+20 \mathrm{mV}$ in experiments like those shown in $A$. C, I-V relationships for the peak inward current and the steady-state outward current in the different groups of granule cells. Note smaller currents in slow-spiking $\mathrm{PrP}^{0 / 0}$ granule cells, in which the inward current attains its negative peak at higher potential. Data are mean \pm SEM (C57BL/6), $n=22 ; \mathrm{C} 57 \times$ Sv129, $n=23 ; \operatorname{PrP}^{0 / 0}$ fast, $n=12 ; \operatorname{PrP}^{0 / 0}$ slow, $n=8$ ).

Laboratories), using 3,3'-diaminobenzidine tetrahydrochloride as chromogen. BrdU-positive cells were counted over 100 strips of $150 \mu \mathrm{m}$ length of external granule cell layer in each of three wild-type and $\operatorname{PrP}^{0 / 0}$ mice.

\section{Results}

In the cerebellum granular layer, $\mathrm{PrP}$ attains high expression levels by the third postnatal week (Salès et al., 2002). By using EM immunostaining, at P17-P22 we observed PrP expression on granule cell somata and dendrites and on mossy fibers of C57 $\times$ Sv129 mice (Fig. 1). At high magnification, PrP demonstrates a punctate immunoprecipitation on the plasma membrane. The extensive expression of PrP on the plasma membrane of glomerular structures suggests a role for the appropriate functioning of the cerebellar circuit. Conversely, in PrP knock-out mice $\left(\mathrm{PrP}^{0 / 0}\right)$ (Büeler et al., 1992), $\operatorname{PrP}$ is absent from all structures forming the mossy fiber-granule cell relay (Lainé et al., 2001). We therefore investigated whether the electrophysiological properties of the mossy fiber-granule cell relay were altered by PrP knock-out at the end of the third postnatal week.

\section{Altered electroresponsiveness in $\operatorname{Pr} \mathrm{P}^{0 / 0}$ granule cells}

As reported in previous investigations on rats and mice cerebella (D'Angelo et al., 1995, 1998; Brickley et al., 1996; Rossi et al., 1998; Chadderton et al., 2004), wildtype granule cells in the present recordings were characterized by fast repetitive spike discharge (Fig. 2A,C, Table 2). Similar properties were also observed in $60 \%(n=$ 12 of 20) of $\mathrm{PrP}^{0 / 0}$ granule cells. However, the remaining $40 \%(n=8$ of 20$)$ of $\mathrm{PrP}^{0 / 0}$ granule cells showed a single or a few slow spikes with marked adaptation, high threshold, small overshoot, and small AHP (Fig. 2B,C, Table 2), and were therefore called "slow-spiking." Slow-spiking $\mathrm{PrP}^{0 / 0}$ granule cells showed very low discharge frequency (often just one spike was generated) compared with fast-spiking (either wildtype or $\mathrm{PrP}^{0 / 0}$ ) granule cells (Fig. $2 \mathrm{D}$, right). Slow-spiking $\mathrm{PrP}^{0 / 0}$ granule cells did not show inward rectification, which was evident in fast-spiking (either wild-type or $\mathrm{PrP}^{0 / 0}$ ) granule cells (Fig. $2 B ; D$, left), and showed a slight reduction in resting membrane potential (Table 2). 
The slow-spiking $\mathrm{PrP}^{0 / 0}$ granule cells were distributed over the $6 \mathrm{~d}$ on which recordings were performed (Fig. $2 D$, inset), and their properties did not depend on series resistance, which was similar regardless of the recorded cell group (compare Table 1). Both in their fast-spiking and slow-spiking pattern, the granule cells had typical membrane capacitance (Table 1) confirming the normal size and homogenous shape observed in EM recordings (Fig. 1) (Lainé et al., 2001). Moreover, regardless of firing pattern, current relaxations elicited by voltage-clamp steps were biphasic with almost identical decay components (the major fast component is related to somatodendritic charging and a smaller slow component is related to axon). The current relaxations were reproduced with a mathematical model supporting axon integrity in all recorded granule cells (see supplemental material, available at www.jneurosci.org).

In the same experiments, whole-cell currents differed when recorded from slow-spiking compared with fast-spiking granule cells (Fig. 3, Table 2). The "transient inward current" (corresponding to a fast $\mathrm{Na}^{+}$current) (Magistretti et al., 2006) was significantly smaller in slow-spiking $\mathrm{PrP}^{0 / 0}$ compared with fast-spiking (either wild-type or $\mathrm{PrP}^{0 / 0}$ ) granule cells and
A
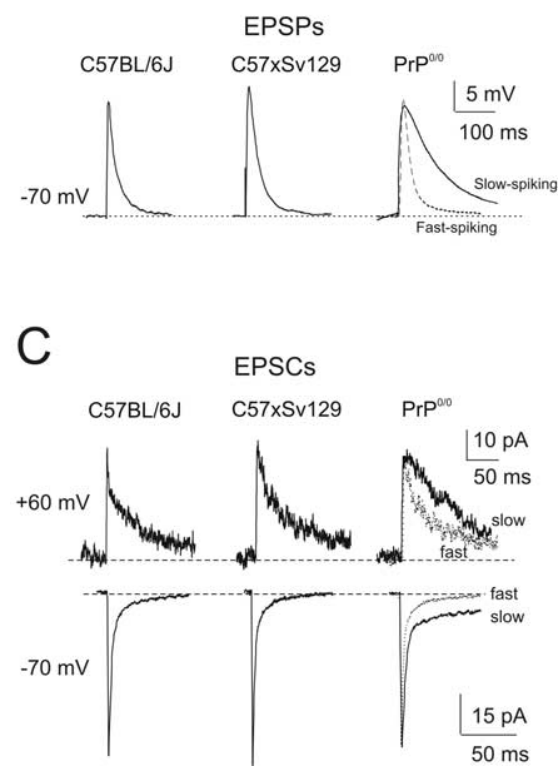

B

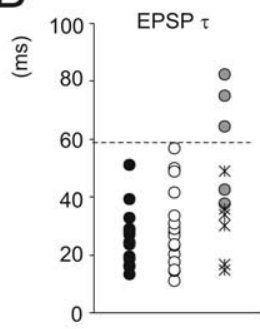

D

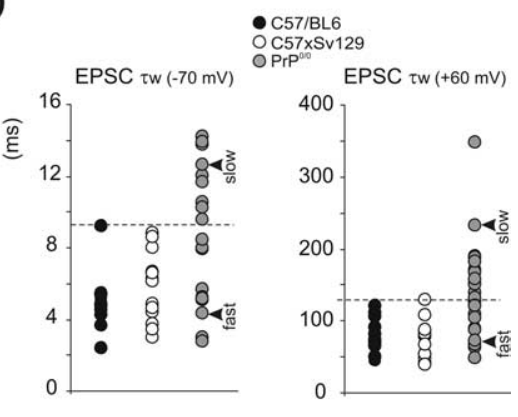

Figure 4. EPSPs and EPSCS. A, Synaptic potentials in wild-type and $\operatorname{PrP}^{0 / 0}$ mice. Superimposed tracings demonstrate similar size but slower kinetics in slow-spiking $\mathrm{PrP}^{0 / 0}$ granule cells compared with fast-spiking (either wild-type or $\operatorname{PrP}^{0 / 0}$ ) granule cells. EPSPs are the averaging of 100 consecutive traces. $\boldsymbol{B}$, The scatter plot shows the decay time constant for EPSPs in the different mice strains. Most slow-spiking $\mathrm{PrP}^{0 / 0}$ data lie outside the region of wild-type data (marked by a dashed line). C, Synaptic currents in $\mathrm{PrP}^{0 / 0}$ and wild-type granule cell at $-70 \mathrm{mV}$ (averaging of 100 consecutive traces) and at $+60 \mathrm{mV}$ (averaging of 10 consecutive traces). Superimposed traces show that, whereas some granule cells have EPSCs comparable with wild type ("fast"), others are markedly slower ("slow"). D. The scatter plot shows the decay time constant for EPSCs in the different mice strains. A proportion of $\mathrm{PrP}^{0 / 0}$ data lies outside the region of wild-type data (marked by a dashed line). The arrowheads indicate the cell used in $C$. reached its inward peak at higher potentials (Fig. 3C). The "transient and persistent outward currents" (corresponding to A-type, delayed rectifier, and calciumdependent $\mathrm{K}^{+}$currents) (Bardoni and Belluzzi, 1993) were also significantly smaller in slow-spiking $\mathrm{PrP}^{0 / 0}$ compared with fastspiking (either wild-type or $\operatorname{PrP}^{0 / 0}$ ) granule cells. Thus, the impairment of intrinsic electroresponsiveness in slow-spiking $\mathrm{PrP}^{0 / 0}$ granule cells was correlated with the abnormal expression of voltage-dependent membrane currents.

In the same recordings, the EPSPs elicited by mossy fiber stimulation showed comparable size but slower kinetics (the decay of EPSP was best described by a single exponential) in slow-spiking $\mathrm{PrP}^{0 / 0}$ compared with fast-spiking (either wild-type or $\mathrm{PrP}^{0 / 0}$ ) granule cells (Fig. 4A,B, Table 2). Therefore, not just intrinsic electroresponsiveness but also synaptic transmission was altered in slow-spiking $\operatorname{PrP}^{0 / 0}$ granule cells.

\section{Altered synaptic transmission at the $\mathrm{PrP}^{0 / 0}$ mossy fiber-granule cell relay}

In specific experiments, glutamate receptor-mediated synaptic currents were measured both at -70 and $+60 \mathrm{mV}$ to identify the differential contribution of the AMPA and NMDA components (Fig. 4C). Actually, whereas the NMDA current is relatively slow and shows a marked increase with depolarization, the AMPA current is much faster and generates large transient responses at negative membrane potentials (D'Angelo et al., 1995, 1999; Cathala et al., 2003). These recordings were performed using $\mathrm{Cs}^{+}$-based intracellular solutions to improve voltage clamp at depolarized potentials, so that $\operatorname{PrP}^{0 / 0}$ cells could not be sorted based on their spike shape.

The AMPA current [estimated at the EPSC peak at $-70 \mathrm{mV}$ :
C57BL/6J, $-62.2 \pm 11.3 \mathrm{pA}(n=13) ; \mathrm{C} 57 \times$ Sv129, $-54.2 \pm$ $\left.14.1 \mathrm{pA}(n=20) ; \mathrm{PrP}^{0 / 0},-46.1 \pm 5.7(n=26)\right]$ and the NMDA current [estimated $25 \mathrm{~ms}$ after the stimulus: C57BL/6J, $59.5 \pm$ $11.5 \mathrm{pA}(n=13) ; \mathrm{C} 57 \times \mathrm{Sv} 129,60.7 \pm 13.9 \mathrm{pA}(n=20) ; \mathrm{PrP}^{0 / 0}$, $43.6 \pm 8.5(n=26)]$ showed similar amplitude in the different strains (Fig. 4C). However, EPSCs were on average slower in $\mathrm{PrP}^{0 / 0}$ than in wild-type granule cells (Fig. 4D). The rate of decay was estimated by performing double-exponential fittings and calculating the weighted time constant $\left(\tau_{\mathrm{w}}\right)$ (see Materials and Methods). At $-70 \mathrm{mV}, \operatorname{PrP}^{0 / 0}$ EPSCs often showed a large late component significantly increasing $\tau_{\mathrm{w}}$ values compared with wild-type mice [C57BL/6J, $5.8 \pm 0.5 \mathrm{~ms}(n=13), p<0.01$; $\mathrm{C} 57 \times$ Sv129, $5.0 \pm 0.5 \mathrm{~ms}(n=20), p<0.001 ; \mathrm{PrP}^{0 / 0}, 8.5 \pm 0.8$ $\mathrm{ms}(n=26)]$. At $+60 \mathrm{mV}$, EPSC decay was also slower in $\mathrm{PrP}^{0 / 0}$ compared with wild-type mice, causing a significant increase in $\tau_{\mathrm{w}}$ [C57BL/6J, $79.0 \pm 6.3 \mathrm{~ms}(n=13), p<0.001 ; \mathrm{C} 57 \times \mathrm{Sv} 129$, $70.9 \pm 6.3 \mathrm{~ms}(n=20), p<0.001 ; \mathrm{PrP}^{0 / 0}, 133.1 \pm 12.8 \mathrm{~ms}(n=$ 26)].

On closer inspection, $\operatorname{PrP}^{0 / 0} \tau_{\mathrm{w}}$ exceeded the value of wildtype EPSCs in $42 \%$ of cases at $-70 \mathrm{mV}$ and in $38.5 \%$ of cases at $+60 \mathrm{mV}$ (Fig. 4D). Thus, the proportion of granule cells with slow $\tau_{\mathrm{w}}$ was similar to that of slow-spiking granule cells identified in current-clamp recordings, suggesting that slow EPSCs explained slow EPSP decay kinetics in $\mathrm{PrP}^{0 / 0}$ granule cells.

\section{Impaired long-term potentiation at the $\mathrm{PrP}^{0 / 0}$ mossy fiber- granule cell relay}

At the mossy fiber-granule cell relay of rat cerebellum, highfrequency stimulation is known to induce a composite form of LTP, in which both synaptic transmission and intrinsic excitability are enhanced (D'Angelo et al., 1999; Armano et al., 2000; Sola 
A
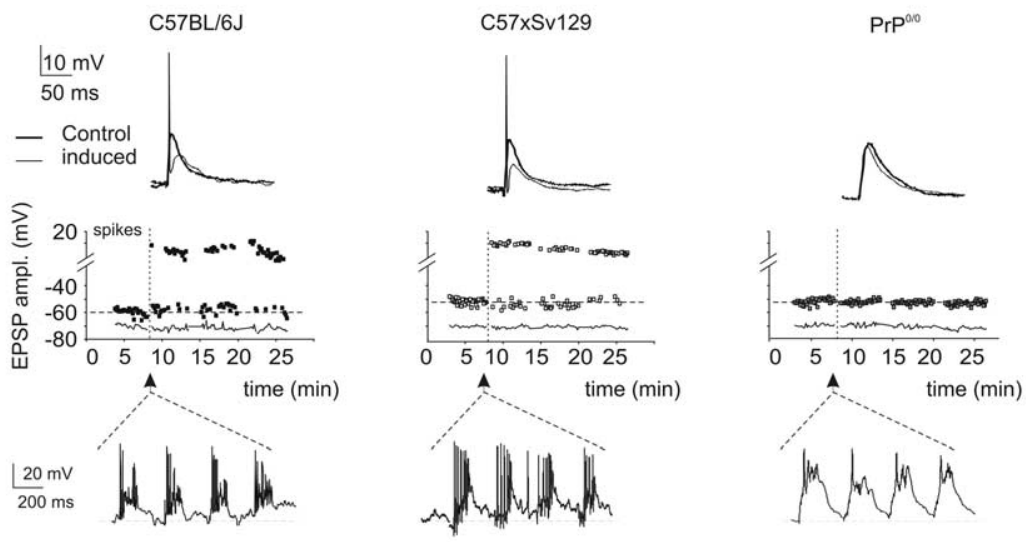

B

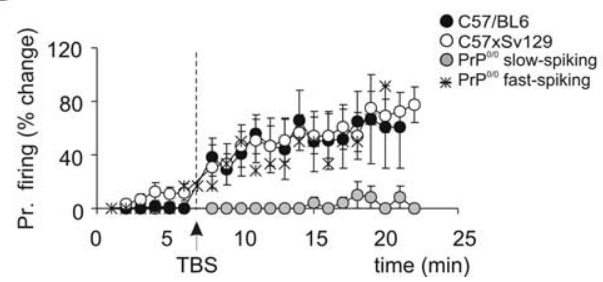

\section{C}

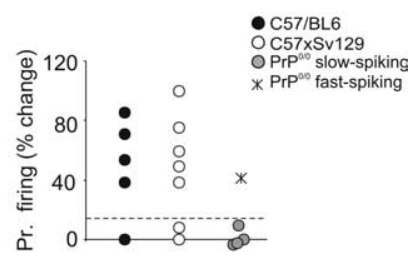

Figure 5. Long-term potentiation of granule cell synaptic excitation. $A$, Effect of TBS delivered from holding potential of -50 $\mathrm{mV}$. Exemplar recordings showing that LTP is manifest as an EPSP increase leading to spike generation in fast-spiking but not in $\mathrm{PrP}^{0 / 0}$ slow-spiking granule cells. The top traces show EPSPs and EPSP-spike complexes. The graphs show the time course of EPSP amplitude changes and transition to EPSP-spike complexes (the continuous lines indicate resting membrane potential, which remained stable throughout). In this and following figures, TBS application is indicated by an arrow. The membrane depolarization elicited by TBS is shown enlarged at the bottom: note the weakness of spike generation in $\mathrm{PrP}^{0 / 0}$ slow-spiking granule cells despite the large average depolarization. $\boldsymbol{B}$, Average time course of the probability of action potential generation before and after TBS. Note long-term potentiation in wild-type and in a single $\mathrm{PrP}^{0 / 0}$ fast-spiking granule cell, whereas no potentiation is

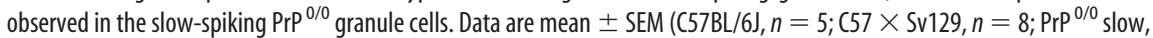
$n=4)$. C, The scatter plot shows the probability of action potential generation after TBS for the different mice strains. The dotted line indicates an arbitrary $10 \%$ threshold for TBS-induced changes. In $\mathrm{PrP}^{0 / 0}$ granule cells, the probability of action potential generation after TBS increased over 10\% only in the fast-spike granule cell.

et al., 2004). In certain conditions in which granule cell activation is weakened, long-term depression (LTD) has been reported (Gall et al., 2005; Mapelli and D'Angelo, 2007).

In current-clamp recordings, LTP was induced by delivering TBS from $-50 \mathrm{mV}$ to improve the depolarizing action of EPSP trains (Fig. 5, Table 3). In fast-spiking granule cells (all wild-type and one $\mathrm{PrP}^{0 / 0}$ ), robust action potential discharge was generated in response to TBS. After TBS, the probability of action potential generation during low-frequency test stimulation increased, precluding EPSP amplitude from being measured (Fig. 5 C). In all of the four slow-spiking $\operatorname{PrP}^{0 / 0}$ granule cells, although TBS had a strong depolarizing action (even stronger than in controls) (Table 3), just a few spikes could be elicited in response to TBS (Fig. $5 A$ ), in line with the alterations in intrinsic firing reported above (compare Fig. 3). After TBS, the probability of action potential generation did not increase and EPSPs remained measurable in most responses (Fig. $5 \mathrm{~A}$, right) without showing any net increase $(-4.7 \pm 7.6 \% ; n=4)$.

Intrinsic excitability was investigated in the same recordings reported in Figure 6. In all fast-spiking granule cells (including the $\operatorname{PrP}^{0 / 0}$ one), TBS enhanced action potential generation and decreased the current needed to reach threshold $\left(I_{\text {th }}\right)$ (Fig. 6A, Table 3). Conversely, in the four slow-spiking $\operatorname{PrP}^{0 / 0}$ cells, no changes were observed. The apparent granule cell input resistance (Fig. $6 B, C$, Table 3 ) was measured from membrane poten- tial changes caused by small current steps in the $10 \mathrm{mV}$ potential range either below $-70 \mathrm{mV}\left(R_{\text {in-low }}\right)$ or above $-70 \mathrm{mV}\left(R_{\text {in- }}\right.$ high). After TBS, $R_{\text {in-high }}$ rapidly increased in all fast-spiking (including the $\operatorname{Pr} \mathrm{P}^{0 / 0}$ one) but not in $\mathrm{PrP}^{0 / 0}$ slow-spiking granule cells. It should be noted that $R_{\text {in-low }}$ remained unchanged in all mice strains, providing an internal control for recording stability (Fig. $6 B, C$, Table 3 ).

In a different group of recordings (Fig. 7), granule cells were voltage clamped with a Cs ${ }^{+}$-based solution, and LTP was induced by TBS while depolarizing the granule cell at $-30 \mathrm{mV}$. At this potential, $\mathrm{Mg}^{2+}$ block is mostly removed from NMDA channels (D'Angelo et al., 1993). As for experiments shown in Figure 4, spikes cannot be monitored and $\operatorname{PrP}^{0 / 0}$ data were pooled. After TBS, the AMPA EPSC in wild-type mice increased, following a similar time course in C57 $\times$ Sv129 and C57BL/6J strains, and remained potentiated throughout the recordings (at least $20 \mathrm{~min}$ after TBS; average time courses are shown in Fig. $7 A, B$ ). At $20 \mathrm{~min}$ after TBS, the EPSC increase was $27.5 \pm 5.9 \%(n=7)$ in C57 $\times$ Sv129 and $32.8 \pm 10.4 \%(n=7)$ in C57BL/6J mice. However, by using the same induction protocol, no LTP was observed in the $\operatorname{PrP}^{0 / 0}$ mice group (1.9 \pm 5.6 ; $n=9 ; p<0.01$ vs either wild-type strains, unpaired $t$ test). At a closer inspection, a single $\mathrm{PrP}^{0 / 0}$ recording showed clear LTP and had EPSCs as fast as in wild type. All the other $\operatorname{PrP}^{0 / 0}$ recordings showed either no LTP or even LTD and had an EPSC decay time constant, $\tau_{\mathrm{w}}$, remarkably larger than normal (compare Fig. 4D). As a whole, LTP was present in $85.7 \%$ (six of seven) granule cells in wild-type mice but just in $22 \%$ (two of nine) granule cells in $\mathrm{PrP}^{0 / 0}$ mice (Fig. $7 C$ ). The low probability of having LTP in $\operatorname{PrP}^{0 / 0}$ granule cells is consistent with the absence of LTP in $\operatorname{PrP}^{0 / 0}$ slow-spiking granule cells.

\section{Juvenile $\operatorname{PrP}^{0 / 0}$ mice show impaired motor control}

Given the marked abnormalities in mossy fiber-granule cell transmission and plasticity and considering the essential role played by the granular layer for cerebellar functioning, we asked whether the $\operatorname{PrP}^{0 / 0}$ mice had impaired sensorimotor control. Motor learning and performance of $\mathrm{PrP}^{0 / 0}$ mice were assessed at P19-P25 and compared with age-matched C57 $\times$ Sv129 control mice ( $n=11$ in both cases) (Dunham and Miya, 1957; Goldowitz et al., 1992; Kashiwabuchi et al., 1995). In the accelerating rotarod test (Fig. 8A), $\mathrm{PrP}^{0 / 0}$ were already worse than $\mathrm{C} 57 \times \mathrm{Sv} 129$ on the first day of training, and then both $\operatorname{PrP}^{0 / 0}$ and $\mathrm{C} 57 \times$ Sv129 mice improved performance with training. However, learning was incomplete in $\mathrm{PrP}^{0 / 0}$ compared with C57 $\times$ Sv129 mice. The greatest difference was observed during the first $4 \mathrm{~d}$ of training $(p<$ 0.001 to $p<0.01$ ). At days $5-7$, when learning tended to plateau, $\operatorname{PrP}^{0 / 0}$ remained stably below the performance of C57 $\times$ Sv129 $(p<0.05)$. In the runway test (Fig. $8 B), \operatorname{PrP}^{0 / 0}$ were worse than C57 $\times$ Sv129 mice on days 1 and $2(p<0.05)$, but there was no statistical difference on days 3-5 (saturation probably occurred 
because the difficulty of test was low). The worse performances of $\mathrm{PrP}^{0 / 0}$ mice was not attributable to a different body development, because $\mathrm{PrP}^{0 / 0}$ and C57 $\times$ Sv129 mice had similar body weight (P19: $8.1 \pm$ $1.2 \mathrm{~g}$ for $\mathrm{PrP}^{0 / 0}$ mice; $7.6 \pm 1.2 \mathrm{~g}$ for $\mathrm{C} 57 \times$ Sv129 mice) (P23: $8.4 \pm 1.2 \mathrm{~g}$ for $\mathrm{PrP}^{0 / 0}$ mice; $8.05 \pm 0.8 \mathrm{~g}$ for $\mathrm{C} 57 \times \mathrm{Sv} 129$ mice) (P25: $9.4 \pm 1.5 \mathrm{~g}$ for $\mathrm{PrP}^{0 / 0}$ mice; $9.4 \pm$ $1.1 \mathrm{~g}$ for C57 $\times$ Sv129 mice). Preliminary experiments with $\mathrm{C} 57 \mathrm{BL} / 6 \mathrm{~J}$ mice revealed aspecific differences, which could be attributed to the attitude to attentive, emotional, and fear responses in this strain (Bearzatto et al., 2005) and to developmental differences, because $\mathrm{C} 57 \mathrm{BL} / 6 \mathrm{~J}$ are still relatively smaller than C57 $\times$ Sv129 and $\mathrm{PrP}^{0 / 0}$ mice at P19.

\section{Alterations at the mossy fiber-granule cell relay disappear in adulthood}

Because it was reported that motor performance in adult $\mathrm{PrP}^{0 / 0}$ mice was normal (Büeler et al., 1992; Herms et al., 1995; Lipp et al., 1998), an obvious question was whether the alterations at the mossy fiber-granule cell relay of juvenile $\mathrm{PrP}^{0 / 0}$ mice disappeared with adulthood. We therefore repeated the critical measurements on $\mathrm{PrP}^{0 / 0}$ mice at $\mathrm{P} 40-\mathrm{P} 50$ (Fig. 9), when cerebellar morphological development is concluded (Altman, 1972; Hámori and Somogyi, 1983) [the intrinsic excitable properties of adult granule cells were recently reported by Goldfarb et al. (2007)]. Interestingly, all adult $\mathrm{PrP}^{0 / 0}$ granule cells (seven of seven) showed fast repetitive firing (Fig. $9 A$ ) and inward rectification (Fig. 9B). Moreover, all of the four cases in which TBS was applied demonstrated LTP, which was manifest both as an increase in the probability of activating EPSP-spike complexes (Fig. 9C,D) and as an increase in intrinsic excitability and cell input resistance (Fig. 9A,B). Thus, adult $\mathrm{PrP}^{0 / 0}$ granule cells did not significantly differ in their major functional properties from fast-spiking neurons in the juvenile stage. It should also be noted that no significant difference was observed between adult $\mathrm{PrP}^{0 / 0}$ mice and age-matched C57BL/6J mice used for control. Minor differences between adult and juvenile granule cells (both in $\operatorname{PrP}^{0 / 0}$ and C57BL/6J mice) are summarized in the supplemental material (available at www.jneurosci.org).

\section{Protracted mitosis in the germinal zone of EGL during the third postnatal week}

The fact that granule cells recovered a normal phenotype at $\mathrm{P} 40$ $\mathrm{P} 50$ suggested that the deficit in $\operatorname{PrP}^{0 / 0}$ mice was transient and
Table 3. Effect of TBS on granule cell response properties

\begin{tabular}{lccc}
\hline & C57BL/6J $(n=5)$ & C57 $\times \operatorname{Sv129}(n=8)$ & $\operatorname{PrP}^{0 / 0}$ slow $(n=4)$ \\
\hline$\Delta \mathrm{AP}_{\text {prob }}(\%)$ & $51.9 \pm 2.3^{*}$ & $55.7 \pm 1.7^{* *}$ & $2.3 \pm 1.7$ \\
$\Delta l_{\text {th }}(\%)$ & $-33.1 \pm 21.2^{*}$ & $-24.1 \pm 21.0^{*}$ & $8.75 \pm 24.0$ \\
$\Delta R_{\text {in-high }}(\%)$ & $42.2 \pm 15.8^{* *}$ & $55.5 \pm 11.8^{* *}$ & $-12.6 \pm 13.2$ \\
$\Delta R_{\text {in-low }}(\%)$ & $6.2 \pm 7.9$ & $0.39 \pm 5.2$ & $7.3 \pm 10.1$ \\
$\mathrm{TBS}_{\text {dep }}(\mathrm{mV})$ & $-44.3 \pm 1.9^{*}$ & $-44.6 \pm 1.8^{*}$ & $-34.1 \pm 4.3$ \\
\hline
\end{tabular}

The table compares percentage changes in wild-type and $\mathrm{PrP}^{0 / 0}$ mice caused by TBS in current-clamp recordings: variation in probability of generating action potentials during synaptic stimulation $\left(\Delta \mathrm{AP}_{\text {prob }}\right)$, variation in current needed to reach spike threshold from the holding potential $\left(\Delta \mathrm{I}_{\mathrm{th}}\right)$, variation in apparent input resistance in the region above or below $-70 \mathrm{mV}\left(\Delta R_{\text {in-high }}\right.$ and $\left.\Delta R_{\text {in-low }}\right)$, and average depolarization during $\operatorname{TBS}\left(\mathrm{TBS}_{\text {dep }}\right)$. The number of observations is reported in parentheses, and statistical significance is reported in comparisons with slow-spiking $\mathrm{PrP}^{0 / 0}$ granule cells.

${ }^{*} p<0.05,{ }^{* *} p<0.01$, unpaired $t$ test.
A
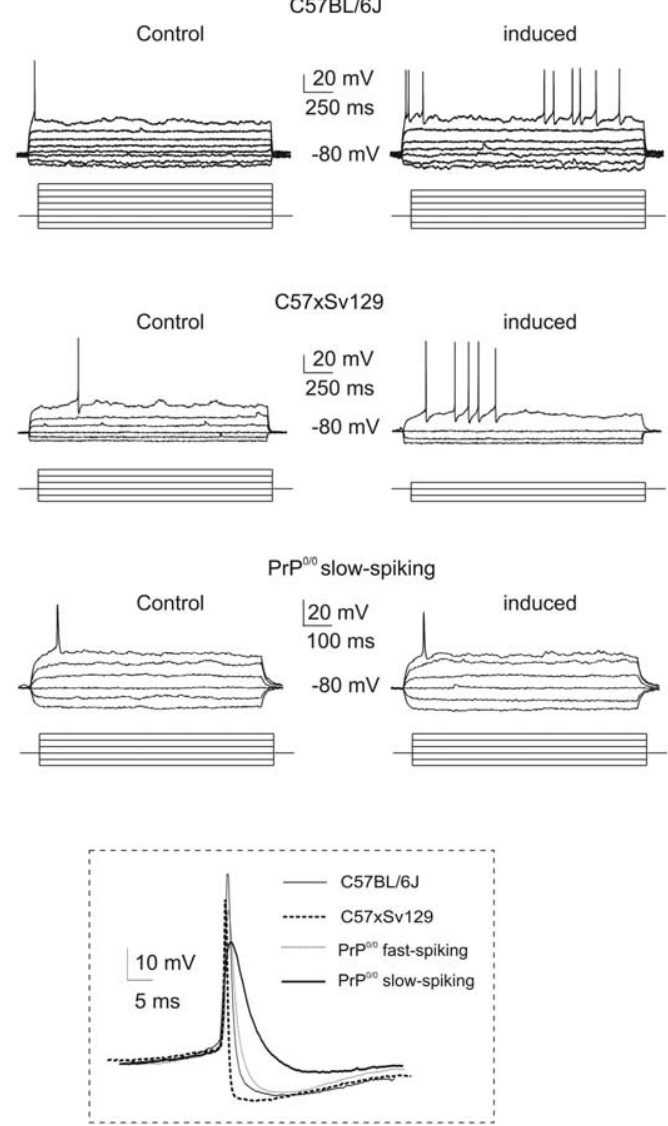

B
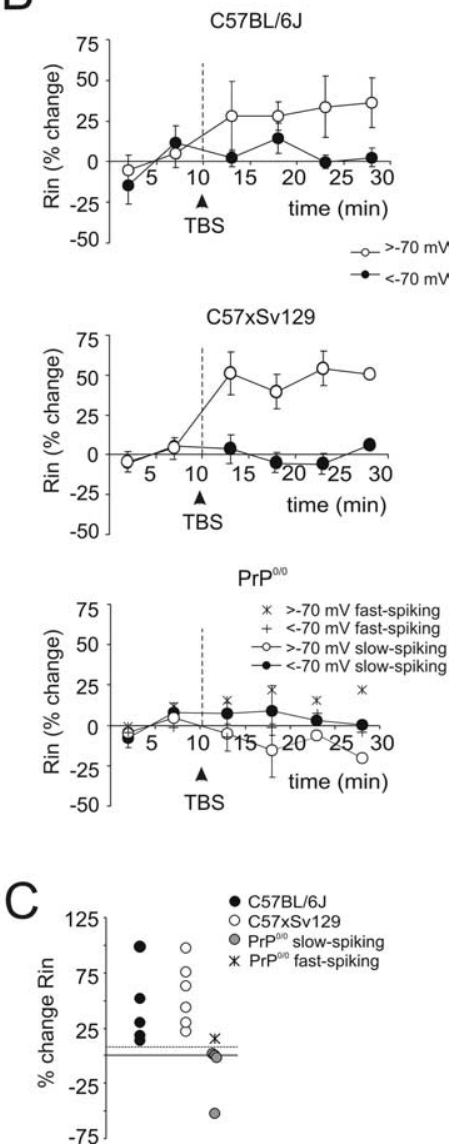

Figure 6. Long-term changes of granule cell intrinsic excitability. $\boldsymbol{A}$, Wild-type and $\mathrm{PrP}^{0 / 0}$ granule cell responses to current injection are compared in recordings with TBS and in time-matched controls. Exemplar traces were taken 10 and $20 \mathrm{~min}$ after the beginning of recordings. As reported in rats (Armano et al., 2000), TBS causes a persistent enhancement of the response to current injection and spike generation in wild-type granule cells. However, no comparable changes are observed in slow-spiking $\mathrm{PrP}^{0 / 0}$ granule cells. The inset shows detail of spikes in the different cell groups, including the single case of fast-spiking $\operatorname{PrP}^{0 / 0}$ granule cell also considered in Figure 5. B. Time course of average input resistance $\left(R_{\text {in }}\right)$ changes after TBS in two subthreshold membrane potential regions, less than $-70 \mathrm{mV}$ and greater than $-70 \mathrm{mV}$. After $\mathrm{TBS}$, in wild-type granule cells and in the single fast-spiking $\mathrm{PrP}^{0 / 0}$ granule cell, $R_{\text {in }}$ increased at potentials greater than $-70 \mathrm{mV}$ but remained stable at potentials less than $-70 \mathrm{mV}$. In slow-spiking $\operatorname{PrP}^{0 / 0}$ granule cells, $R_{\text {in }}$ remained unchanged at all subthreshold membrane potentials. Data are mean \pm SEM (C57BL/6J, $n=5 ; C 57 \times$ Sv129, $n=8$; $\mathrm{PrP}^{0 / 0}$ slow, $\left.n=4\right)$. $C$, The scatter plot shows $R_{\text {in }}$ changes for the different mice strains. Note that an increase $>10 \%$ (dashed line) is present in all granule cells in wild-type mice and in the fast-spiking $\mathrm{PrP}^{0 / 0}$ granule cell, whereas slowspiking $\mathrm{PrP}^{0 / 0}$ granule cells have no increase or even decrease in $R_{\text {in }}$. Measures were taken $15 \mathrm{~min}$ after TBS.

related to the developmental period. Because PrP was reported to affect the early stages of neuronal development (Manson et al., 1992; Graner et al., 2000; Martins et al., 2002; Steele et al., 2006), we investigated granule cell proliferation in the germinal zone of the EGL by using BrdU immunostaining in sagittal sections of the cerebellar vermis taken at different ages (Fig. 10). As expected, the 
A

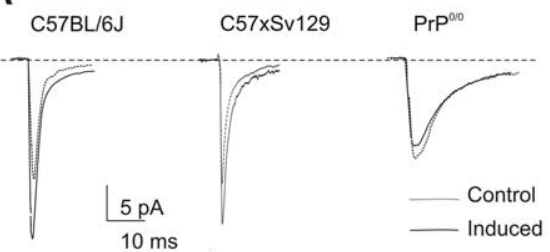

B

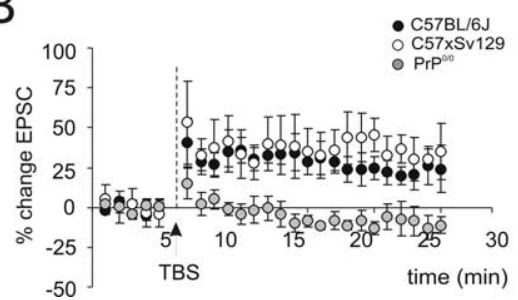

C

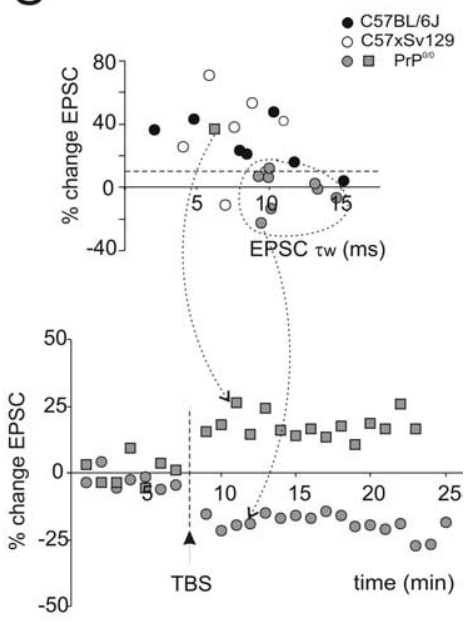

Figure 7. Long-term changes in mossy fiber-granule cell EPSCS. A, Average EPSCS (100 tracings) obtained during control and 20 min after TBS application are shown superimposed in $57 \times$ Sv129, in C57BL/6J, and in a representative $\mathrm{PrP}^{0 / 0}$ granule cell. After TBS, EPSCs increased in the wild-type but not in the $\mathrm{PrP}^{0 / 0}$ granule cell. $\boldsymbol{B}$, Average time course of average EPSC amplitude changes in $57 \times$ Sv129, C57BL/6J, and PrP 0/0 granule cells. TBS was applied while holding membrane potential at $-30 \mathrm{mV}$. Note the persistent increase in EPSC amplitude after TBS in C57 $\times$ Sv129 and C57BL/6J but not in pooled PrP ${ }^{0 / 0}$ granule cells. Data are mean \pm SEM (C57BL/6J, $n=7 ;\left(57 \times \operatorname{Sv} 129, n=7 ; \operatorname{PrP}^{0 / 0}, n=9\right)$. C, The top plot correlates EPSC amplitude changes after TBS for the different mice strains with the EPSC decay time constant, $\tau_{w}$ at $-70 \mathrm{mV}$. Note that a persistent $>10 \%$ increase (dashed line) is present in six of seven cells in wild-type mice but just in two of nine cells in $\mathrm{PrP}^{0 / 0}$ mice. Most PrP ${ }^{0 / 0}$ granule cells with large $\tau_{\mathrm{w}}$ are in the bottom right portion of the plot, and some of them show LTD. All data were taken $15 \mathrm{~min}$ after TBS. The time course of two exemplar recordings, one showing LTP and one LTD, is reported at the bottom.

A

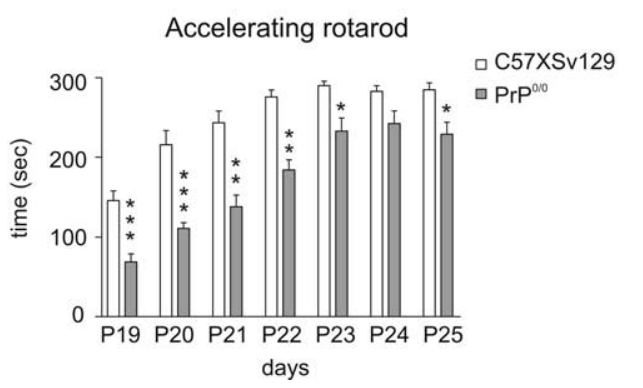

B

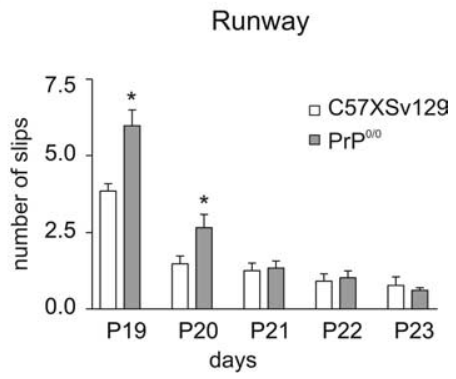

Figure 8. Motor performance and learning in $\operatorname{PrP}^{0 / 0}$ mice. $A$, Performance in the accelerating rotarod test for $C 57 \times$ $\mathrm{Sv} 129$ and $\mathrm{PrP}{ }^{0 / 0}$ mice at $\mathrm{P} 19-\mathrm{P} 25$. The latency to fall off the rotarod during the learning session is lower for $\mathrm{Pr} \mathrm{P}^{0 / 0}$ mice compared with $C 57 \times$ Sv129 mice. $B$, Performance in the runway test of $C 57 \times$ Sv129 and PrP ${ }^{0 / 0}$ mice at P19-P23. At the beginning of training, the runway test confirms the impairment in motor performance in $\mathrm{PrP}^{0 / 0}$ mice with a higher number of slips compared with $C 57 \times$ Sv129 mice. Data are mean \pm SEM $\left(C 57 \times\right.$ Sv129, $\left.n=11 ; \operatorname{PrP}^{0 / 0}, n=11\right)$, and the statistical significance of differences of $\operatorname{Pr}^{0 / 0}$ versus $C 57 \times$ Sv129 mice is indicated $\left({ }^{* * *} p<0.001,{ }^{* *} p<0.01,{ }^{*} p<\right.$ 0.05, two-way ANOVA).

wild-type granule cells actively duplicated until the end of the second postnatal week (Altman, 1972). Conversely, duplication in the $\operatorname{PrP}^{0 / 0}$ mice continued also during the third postnatal week, suggesting that $\mathrm{PrP}$ was involved in controlling granule cell proliferation.

\section{Discussion}

The central observation in this study is that PrP knock-out causes abnormal functioning of the cerebellar mossy fibergranule cell relay and impairs motor control in juvenile mice. In $\mathrm{PrP}^{0 / 0}$ mice, a large proportion of granule cells $(\sim 40 \%)$ showed slow nonovershooting nonrepetitive action poten- tials, slow EPSPs, and no inward rectification. Moreover, the slow-spiking $\mathrm{PrP}^{0 / 0}$ granule cells were unable to generate LTP with the TBS protocol. The disturbances were evident during the third postnatal week but disappeared thereafter, supporting a major role of $\mathrm{PrP}$ in granular layer formation and motor control (Salès et al., 2002; Nicolas et al., 2007).

The slow-spiking $\mathrm{PrP}^{0 / 0}$ granule cells bear a striking resemblance to an immature phenotype by showing nonovershooting nonrepetitive spikes, no inward rectification, and relatively high resting potential (D'Angelo et al., 1997). Like wild-type immature granule cells, slowspiking $\mathrm{PrP}^{0 / 0}$ granule cells have small $\mathrm{Na}^{+}, \mathrm{Ca}^{2+}$, and $\mathrm{K}^{+}$currents (D'Angelo et al., 1994; Rossi et al., 1998) and lack inward rectification (Rossi et al., 1998). Moreover, immature granule cells show slow EPSPs in association with slow NMDA currents (D'Angelo et al., 1993; Farrant et al., 1994; Rumbaugh and Vicini, 1999; Cathala et al., 2000; Rossi et al., 2002; Wall et al., 2002). In normal mice, the transition from immature to mature excitable patterns occurs soon after granule cell migrate from the external to internal granular layer and proceeds throughout postnatal weeks 1 and 2: in week 3 , electrophysiological parameters are stabilized and immature slowspiking granule cells disappear [for mice, see Rossi et al. (1998); for the rat, see D'Angelo et al. $(1993,1994,1997)]$. The observation of protracted mitosis in the germinal zone of the EGL suggests that, in $\mathrm{PrP}^{0 / 0}$ mice, immature granule cells are abnormally supplied to the granular layer all along the third postnatal week. These neurons will eventually mature explaining why only a part of granule cells at P20 are slow-spiking and why at P40$\mathrm{P} 50$ slow-spiking $\mathrm{PrP}^{0 / 0}$ granule cells disappear (cf. Goldfarb et al., 2007). In addition to the arrival of new immature granule cells, other PrP-dependent mechanisms may be altered in granule cells once migration is concluded. A reduced L-type $\mathrm{Ca}^{2+}$-channel expression, which was observed in $\mathrm{PrP}^{0 / 0}$ granule cells in culture (Herms et al., 2000; Fuhrmann et al., 2006) (see also Korte et al., 2003), could reduce spike afterhyperpolarization by weakening activation of calcium-dependent K-channels (Colling et al., 1996; Herms et al., 2001) and contribute to alter repetitive spike discharge.

LTP was altered only in granule cells with immature phenotype and could therefore also be dependent on the altered developmental program of the granule cells. However, the alteration of LTP could be more complex and involve additional mechanisms. In fact, membrane depolarization during TBS 
was larger in slow-spiking $\mathrm{PrP}^{0 / 0}$ than in fastspiking granule cells, and the slow time course of NMDA EPSCs suggests that $\mathrm{Ca}^{2+}$ influx, which is needed for LTP induction (D'Angelo et al., 1999; Armano et al., 2000; Rossi et al., 2002; Gall et al., 2005), might be even larger in $\operatorname{PrP}^{0 / 0}$ than in wild type. Therefore, the mechanisms of dysfunction may involve alterations in intracellular $\mathrm{Ca}^{2+} \mathrm{dy}-$ namics, which have been reported in $\mathrm{PrP}^{0 / 0}$ cultured cerebellar granule cells (Herms et al., 2000). A defect in nitric oxide signaling (Keshet et al., 1999), which is required for mossy fiber-granule cell LTP (Maffei et al., 2003), could explain the absence of presynaptic changes needed to generate EPSC potentiation (Sola et al., 2004). Therefore, PrP knock-out may directly affect the LTP mechanism, as originally proposed for hippocampal synapses (Collinge et al., 1994; Curtis et al., 2003; Maglio et al., 2004, 2006) (but see Lledo et al., 1996).

These results suggest a hypothesis on how $\operatorname{PrP}$ could interact with granular layer functions. The absence of a timely arrest of proliferation in the EGL germinal zone may reflect the absence of signals normally provided by PrP to the biochemical cascades regulating granule cell apoptosis (Nicolas et al., 2007). Thus, the mechanism of PrP action, at least in part, could reside in a protracted proliferation in the germinal zone of the EGL supplying the granular layer with immature granule cells. Moreover, because PrP expression proceeds in parallel with the development of granule cell excitable functions [cf. D'Angelo et al. $(1994,1997)$ and Rossi et al. (1998) to Salès et al. (2002)] and is abundantly expressed in mature granule cells and presynaptic mossy fiber terminals, the effects of PrP may continue in the granular layer. The coexistence of mature with immature granule cells at early stages and the full recovery of mature excitability and LTP at later stages indicate that, despite the altered developmental program in PrP knock-out mice, mature functions are finally recovered possibly through the engagement of compensatory mechanisms. It seems less likely that slow-spiking granule cells reflect ongoing degeneration, because no gross anatomical abnormalities are apparent in the adulthood (Lainé et al., 2001), as it would be expected with an extended granule cells loss [e.g., in the weaver mutation (Rossi et al., 1998)].

The multiple granular layer alterations in the $\operatorname{PrP}^{0 / 0}$ mice could each contribute to impair cerebellar functioning in their own way. Slow EPSPs and action potentials are expected to reduce the velocity and temporal precision of mossy fiber-granule cell synaptic transmission (D'Angelo et al., 1995, 1997; Cathala et al., 2003), the absence of repetitive firing to prevent coding of afferent information into spike bursts (Chadderton et al., 2004; Jörntell and Ekerot, 2006; Nieus et al., 2006; Rancz et al., 2007), and the absence of LTP to limit granular layer changes by specific input patterns (Mapelli and D'Angelo, 2007). This could bring about a diffused impairment of synaptic transmission and plasticity throughout the cerebellar network (Casado et al., 2002; Brunel et al., 2004). Although $\operatorname{PrP}^{0 / 0}$ functional alterations occur also in other parts of the brain [e.g., the hippocampus (Colling et al., 1996) (but see Lledo et al., 1996; Johnston et al., 1998)], the
B
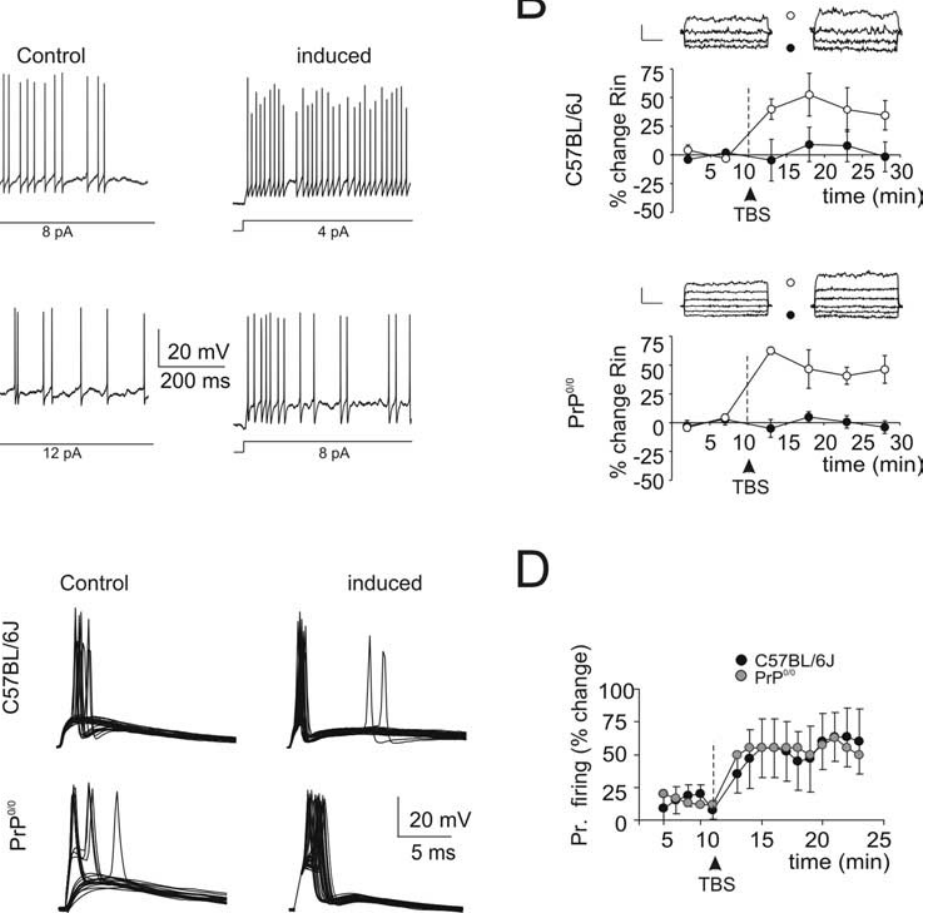

Figure 9. Intrinsic excitability and synaptic plasticity at the adult mossy fiber-granule relay. $\boldsymbol{A}, \mathrm{Re}-$ ponses to current injection elicited from $-80 \mathrm{mV}$ in adult granule cells (C57BL/6J at P42 and PrP ${ }^{0 / 0}$ at ubthreshold membrane potential regions, less than $-70 \mathrm{mV}(\mathbf{O})$ and greater than $-70 \mathrm{mV}(\bigcirc)$. After $\mathrm{BS}$, both in wild-type and $\mathrm{PrP}^{0 / 0}$ granule cells, $R_{\text {in }}$ increased at potentials greater than $-70 \mathrm{mV}$ but stable at potentials less than $-70 \mathrm{mV}$. The top traces show voltage responses obtained before by an arrow, and data are reported as mean \pm SEM. C, Effect of TBS on granule cell synaptic excitation. Sets of traces (initial potential, $-70 \mathrm{mV}$ ) taken from the same cells reported in $\boldsymbol{A}$ show that LTP manifested with an EPSP increase and with a higher probability of EPSP spike coupling both in C57BL/6J and $\mathrm{PrP} \mathrm{P}^{0 / 0}$ $n=4$ both in $\left(57 \mathrm{BL} / 6 \mathrm{~J}\right.$ and $\operatorname{PrP}^{0 / 0}$ granule cells). Note the occurrence of LTP in both strains. TBS application is indicated by an arrow, and data are reported as mean \pm SEM.

marked granular layer abnormalities are likely to play a relevant role in altering sensorimotor control in the runway and rotarod tests.

In conclusion, these results suggest an active role of $\operatorname{PrP}$ in the functional maturation of the mossy fiber-granule cell relay of cerebellum implying consequences for motor control and reinforcing the evidence for an active role of $\operatorname{PrP}$ in brain development (Manson et al., 1992; Graner et al., 2000; Martins et al., 2002; Steele et al., 2006). The reason why, in adult $\operatorname{PrP}^{0 / 0}$ mice, behavioral tests appeared normal (Büeler et al., 1992; Herms et al., 1995; Lipp et al., 1998), is probably because slow-spiking granule cells eventually recover a normal fastspiking phenotype and synaptic plasticity. The potential impact of the temporary disruption of the cerebellar circuit during a time window critical for sensorimotor development (Altman and Sudarshan, 1975) remains to be determined, but it may have a reflection in some of the late motor, cognitive, and emotional abnormalities of $\mathrm{PrP}^{0 / 0}$ mice (Roesler et al., 1999; Walz et al., 2002; Criado et al., 2005). In this context, it should be noted that the late-onset cerebellar ataxia observed in different $\mathrm{PrP}^{0 / 0}$ strains is a distinct phenomenon, which 
A
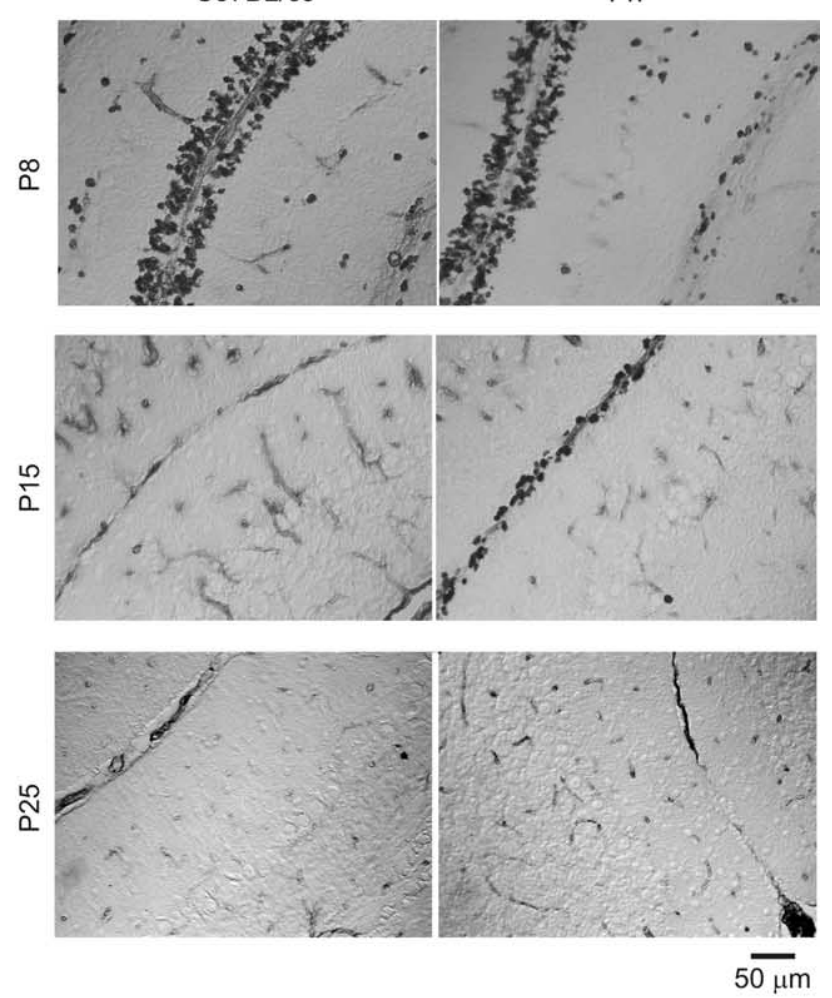

B

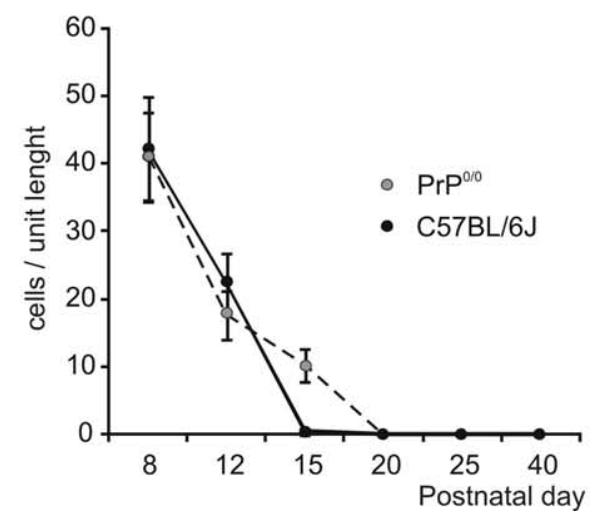

Figure 10. Granule cell proliferation in the germinal zone of the external granular layer. $\boldsymbol{A}$, Anti-BrdU-stained cerebellum of wild-type and PrP ${ }^{0 / 0}$ mice at different postnatal ages. At P8, a multilayered germinal zone is similarly stained by BrdU both in the EGL of wild-type and $\mathrm{PrP}$ 0/0 mice. At P15, in wild-type mice, BrdU-positive cells are no longer present, whereas they persist in $\mathrm{PrP}{ }^{0 / 0}$ mice. At $\mathrm{P} 25$, no BrdU-positive cells are detectable either in wild-type or $\mathrm{PrP}^{0 / 0}$ mice. $B$, The graph shows the number of BrdU-positive cells per unit length in wild-type and $\mathrm{Pr} \mathrm{P}^{0 / 0}$ mice. It should be noted that only in the $\mathrm{PrP}^{0 / 0}$ mice proliferation continues for another week beyond P15 (data are reported as mean $\pm \mathrm{SEM} ; n=3$ ).

arises much later (after 60 postnatal weeks) and depends on mutation in the homologous $D p l$ gene (Sakaguchi et al., 1996; Katamine et al., 1998; Moore et al., 2001; Behrens and Aguzzi, 2002).

\section{References}

Altman J (1972) Postnatal development of the cerebellar cortex in the rat. III. Maturation of the components of the granular layer. J Comp Neurol 145:465-513.
Altman J, Sudarshan K (1975) Postnatal development of locomotion in the laboratory rat. Anim Behav 23:896-920.

Armano S, Rossi P, Taglietti V, D’Angelo E (2000) Long-term potentiation of intrinsic excitability at the mossy fiber-granule cell synapse of rat cerebellum. J Neurosci 20:5208-5216.

Bardoni R, Belluzzi O (1993) Kinetic study and numerical reconstruction of A-type current in granule cells of rat cerebellar slices. J Neurophysiol 69:2222-2231.

Bearzatto B, Servais L, Cheron G, Schiffmann SN (2005) Age dependence of strain determinant on mice motor coordination. Brain Res 1039:37-42.

Behrens A, Aguzzi A (2002) Small is not beautiful: antagonizing functions for the prion protein $\operatorname{PrP}^{\mathrm{C}}$ and its homologue Dpl. Trends Neurosci 25:150-154.

Bliss TV, Collingridge GL (1993) A synaptic model of memory: long-term potentiation in the hippocampus. Nature 361:31-39.

Brickley SG, Cull-Candy SG, Farrant M (1996) Development of a tonic form of synaptic inhibition in rat cerebellar granule cells resulting from persistent activation of $\mathrm{GABA}_{\mathrm{A}}$ receptors. J Physiol 497:753-759.

Brunel N, Hakim V, Isope P, Nadal JP, Barbour B (2004) Optimal information storage and the distribution of synaptic weights: perceptron versus Purkinje cell. Neuron 43:745-757.

Büeler H, Fischer M, Lang Y, Bluethmann H, Lipp HP, DeArmond SJ, Prusiner SB, Aguet M, Weissmann C (1992) Normal development and behavior of mice lacking the neuronal cell-surface PrP protein. Nature 356:577-582.

Casado M, Isope P, Ascher P (2002) Involvement of presynaptic N-methylD-aspartate receptors in cerebellar long-term depression. Neuron 33:123-130.

Cathala L, Misra C, Cull-Candy S (2000) Developmental profile of the changing properties of NMDA receptors at cerebellar mossy fiber-granule cell synapses. J Neurosci 20:5899-5905.

Cathala L, Brickley S, Cull-Candy S, Farrant M (2003) Maturation of EPSCs and intrinsic membrane properties enhances precision at a cerebellar synapse. J Neurosci 23:6074-6085.

Chadderton P, Margrie TW, Häusser M (2004) Integration of quanta in cerebellar granule cells during sensory processing. Nature 428:856-860.

Colling SB, Collinge J, Jefferys JG (1996) Hippocampal slices from prion protein null mice: disrupted $\mathrm{Ca}^{2+}$-activated $\mathrm{K}^{+}$currents. Neurosci Lett 209:49-52.

Collinge J, Whittington MA, Sidle KC, Smith CJ, Palmer MS, Clarke AR, Jefferys JG (1994) Prion protein is necessary for normal synaptic function. Nature 370:295-297.

Criado JR, Sánchez-Alavez M, Conti B, Giacchino JL, Wills DN, Henriksen SJ, Race R, Manson JC, Chesebro B, Oldstone MB (2005) Mice devoid of prion protein have cognitive deficits that are rescued by reconstitution of PrP in neurons. Neurobiol Dis 19:255-265.

Curtis J, Errington M, Bliss T, Voss K, MacLeod N (2003) Age-dependent loss of PTP and LTP in the hippocampus of PrP null mice. Neurobiol Dis 13:55-62.

D’Angelo E, Rossi P, Taglietti V (1993) Different proportions of N-methylD-aspartate and non- $N$-methyl-D-aspartate receptor currents at the mossy fiber-granule cell synapse of developing rat cerebellum. Neuroscience 53:121-130.

D’Angelo E, Rossi P, De Filippi G, Magistretti J, Taglietti V (1994) The relationship between synaptogenesis and expression of voltagedependent currents in cerebellar granule cells in situ. J Physiol Paris 88:197-207.

D’Angelo E, De Filippi G, Rossi P, Taglietti V (1995) Synaptic excitation of individual rat cerebellar granule cells in situ: evidence for the role of NMDA receptors. J Physiol 484:397-413.

D’Angelo E, De Filippi G, Rossi P, Taglietti V (1997) Synaptic activation of $\mathrm{Ca}^{2+}$ action potentials in immature rat cerebellar granule cells in situ. J Neurophysiol 78:1631-1642.

D’Angelo E, De Filippi G, Rossi P, Taglietti V (1998) Ionic mechanism of electroresponsiveness in cerebellar granule cells implicates the action of a persistent sodium current. J Neurophysiol 80:493-503.

D’Angelo E, Rossi P, Armano S, Taglietti V (1999) Evidence for NMDA and mGlu receptor-dependent long-term potentiation of mossy fiber-granule cell transmission in rat cerebellum. J Neurophysiol 81:277-287.

Demart S, Fournier JG, Creminon C, Frobert Y, Lamoury F, Marce D, Lasmézas C, Dormont D, Grassi J, Deslys JP (1999) New insight into abnor- 
mal prion protein using monoclonal antibodies. Biochem Biophys Res Commun 265:652-657.

Dunham NW, Miya TS (1957) A note on a simple apparatus for detecting neurological deficit in rats and mice. J Am Pharm Assoc Am Pharm Assoc (Baltim) 46:208-209.

Eccles JC, Ito M, Szentagothai J (1967) The cerebellum as a neuronal machine. Berlin: Springer.

Farrant M, Feldmeyer D, Takahashi T, Cull-Candy SG (1994) NMDAreceptor channel diversity in the developing cerebellum. Nature 368:335-339.

Ferrer I, Puig B, Blanco R, Martí E (2000) Prion protein deposition and abnormal synaptic expression in the cerebellum in Creutzfeldt-Jacob disease. Neuroscience 97:715-726.

Fuhrmann M, Bittner T, Mitteregger G, Haider N, Moosmang S, Kretzschmar H, Herms J (2006) Loss of the cellular prion protein affects the $\mathrm{Ca}^{2+}$ homeostasis in hippocampal CA1 neurons. J Neurochem 98:1876-1885.

Gall D, Prestori F, Sola E, D’Errico A, Roussel C, Forti L, Rossi P, D’Angelo E (2005) Intracellular calcium regulation by burst discharge determines bidirectional long-term synaptic plasticity at the cerebellum input stage. J Neurosci 25:4813-4822.

Goldfarb M, Schoorlemmer J, Williams A, Diwakar S, Wang Q, Huang X, Giza J, Tchetchik D, Kelley K, Vega A, Matthews G, Rossi P, Ornitz DM, D’Angelo E (2007) Fibroblast growth factor homologous factors control neuronal excitability through modulation of voltage-gated sodium channels. Neuron 55:449-463.

Goldowitz D, Moran TH, Wetts R (1992) Mouse chimeras in the study of genetic and structural determinants of behavior. In: Techniques for the genetic analysis of brain and behavior, pp 271-290. Amsterdam: Elsevier.

Graner E, Mercadante AF, Zanata SM, Forlenza OV, Cabral AL, Veiga SS, Juliano MA, Roesler R, Walz R, Minetti A, Izquierdo I, Martins VR, Brentani RR (2000) Cellular prion protein binds laminin and mediates neuritogenesis. Brain Res Mol 76:85-92.

Hámori J, Somogyi J (1983) Differentiation of cerebellar mossy fiber synapses in the rat: a quantitative electron microscope study. J Comp Neurol 220:365-377.

Hansel C, Linden DJ, D'Angelo E (2001) Beyond parallel fiber LTD: the diversity of synaptic and non-synaptic plasticity in the cerebellum. Nat Neurosci 4:467-475.

Harris DA, True HL (2006) New insights into prion structure and toxicity. Neuron 50:353-357.

Herms J, Tings T, Gall S, Madlung A, Giese A, Siebert H, Schürmann P, Windl O, Brose N, Kretzschmar H (1999) Evidence of presynaptic location and function of the prion protein. J Neurosci 19:8866-8875.

Herms JW, Kretzchmar HA, Titz S, Keller BU (1995) Patch-clamp analysis of synaptic transmission to cerebellar Purkinje cells of prion protein knockout mice. Eur J Neurosci 7:2508-2512.

Herms JW, Korte S, Gall S, Schneider I, Dunker S, Kretzschmar HA (2000) Altered intracellular calcium homeostasis in cerebellar granule cells of prion protein-deficient mice. J Neurochem 75:1487-1492.

Herms JW, Tings T, Dunker S, Kretzschmar HA (2001) Prion protein affects $\mathrm{Ca}^{2+}$-activated $\mathrm{K}^{+}$currents in cerebellar Purkinje cells. Neurobiol Dis 8:324-330.

Johnston AR, Fraser JR, Jeffrey M, MacLeod N (1998) Synaptic plasticity in the $\mathrm{CA} 1$ area of the hippocampus of scrapie-infected mice. Neurobiol Dis 5:188-195.

Jörntell H, Ekerot CF (2006) Properties of somatosensory synaptic integration in cerebellar granule cells in vivo. J Neurosci 26:11786-11797.

Kashiwabuchi N, Ikeda K, Araki K, Hirano T, Shibuki K, Takayama C, Inoue Y, Kutsuwada T, Yagi T, Kang Y, Aizawa S, Mishina M (1995) Impairment of motor coordination, Purkinje cell synapse formation, and cerebellar long-term depression in GluR delta 2 mutant mice. Cell 81:245-252.

Katamine S, Nishida N, Sugimoto T, Noda T, Sakaguchi S, Shigematsu K, Kataoka Y, Nakatani A, Hasegawa S, Moriuchi R, Miyamoto T (1998) Impaired motor coordination in mice lacking prion protein. Cell Mol Neurobiol 18:731-742.

Keshet GI, Ovadia H, Taraboulos A, Gabizon R (1999) Scrapie-infected mice share abnormal localization and activity of neuronal nitric oxide synthase. J Neurochem 72:1124-1231.

Korte S, Vassallo N, Kramer ML, Kretzschmar HA, Herms J (2003) Modu- lation of L-type voltage-gated calcium channels by recombinant prion protein. J Neurochem 87:1037-1042.

Lainé J, Marc ME, Sy MS, Axelrad H (2001) Cellular and subcellular morphological localization of normal prion protein in rodent cerebellum. Eur J Neurosci 14:47-56.

Legname G, Nelken P, Guan Z, Kanyo ZF, DeArmond SJ, Prusiner SB (2002) Prion and Doppel proteins bind to granule cells of the cerebellum. Proc Natl Acad Sci U S A 99:16285-16290.

Lipp HP, Stagliar-Bozicevic M, Fischer M, Wolfer DP (1998) A 2-year longitudinal study of swimming navigation in mice devoid of the prion protein: no evidence for neurological anomalies or spatial learning impairments. Behav Brain Res 95:47-54.

Lledo PM, Tremblay P, DeArmond SJ, Prusiner SB, Nicoll RA (1996) Mice deficient for prion protein exhibit normal neuronal excitability and synaptic transmission in the hippocampus. Proc Natl Acad Sci U S A 93:2403-2407.

Maffei A, Prestori F, Shibuki K, Rossi P, Taglietti V, D’Angelo E (2003) NO enhances presynaptic currents during cerebellar mossy fiber-granule cell LTP. J Neurophysiol 90:2478-2483.

Magistretti J, Castelli L, Forti L, D’Angelo E (2006) Kinetic and functional analysis of transient, persistent and resurgent sodium currents in rat cerebellar granule cells in situ: an electrophysiological and modeling study. J Physiol 573:83-106.

Maglio LE, Perez MF, Martins VR, Brentani RR, Ramirez OA (2004) Hippocampal synaptic plasticity in mice devoid of cellular prion protein. Brain Res Mol Brain Res 131:58-64.

Maglio LE, Martins VR, Izquierdo I, Ramirez OA (2006) Role of cellular prion protein on LTP expression in aged mice. Brain Res 1097:11-18.

Mallucci GR, Ratté S, Asante EA, Linehan J, Gowland I, Jefferys JG, Collinge J (2002) Post-natal knockout of prion protein alters hippocampal CA1 properties, but does not result in neurodegeneration. EMBO J 21:202-210.

Manson J, West JD, Thomson V, McBride P, Kaufman MH, Hope J (1992) The prion protein gene: a role in mouse embryogenesis? Development 115:117-122.

Mapelli J, D’Angelo E (2007) The spatial organization of long-term synaptic plasticity at the input stage of cerebellum. J Neurosci 27:1285-1296.

Martins VR, Linden R, Prado MA, Walz R, Sakamoto AC, Izquierdo I, Brentani RR (2002) Cellular prion protein: on the road for functions. FEBS Lett 512:25-28.

Moore RC, Mastrangelo P, Bouzamondo E, Heinrich C, Legname G, Prusiner SB, Hood L, Westaway D, DeArmond SJ, Tremblay P (2001) Doppelinduced cerebellar degeneration in transgenic mice. Proc Natl Acad Sci U S A 98:15288-15293.

Nicolas O, Gavín R, Braun N, Ureña JM, Fontana X, Soriano E, Aguzzi A, del Río JA (2007) Bcl-2 overexpression delays caspase-3 activation and rescues cerebellar degeneration in prion-deficient mice that overexpress amino-terminally truncated prion. FASEB J 21:3107-3117.

Nieus T, Sola E, Mapelli J, Saftenku E, Rossi P, D’Angelo E (2006) LTP regulates burst initiation and frequency at mossy-fiber granule cell synapses of rat cerebellum: experimental observations and theorical predictions. J Neurophysiol 95:686-699.

Prusiner SB (1998) Prions. Proc Natl Acad Sci U S A 95:13363-13383.

Rancz EA, Ishikawa T, Duguid I, Chadderton P, Mahon S, Häusser M (2007) High-fidelity transmission of sensory information by single cerebellar mossy fibre boutons. Nature 450:1245-1248.

Roesler R, Walz R, Quevedo J, de-Paris F, Zanata SM, Graner E, Izquierdo I, Martins VR, Brentani RR (1999) Normal inhibitory avoidance learning and anxiety, but increased locomotor activity in mice devoid of $\operatorname{Pr} \mathrm{P}(\mathrm{C})$. Brain Res Mol Brain Res 71:349-353.

Rossi P, D’Angelo E, Magistretti J, Toselli M, Taglietti V (1994) Agedependent expression of high-voltage activated calcium currents during cerebellar granule cell development in situ. Pflugers Arch 429:107-116.

Rossi P, De Filippi G, Armano S, Taglietti V, D’Angelo E (1998) The weaver mutation causes a loss of inward rectifier current regulation in premigratory granule cells of mice cerebellum. J Neurosci 18:3537-3547.

Rossi P, Sola E, Taglietti V, Borchardt T, Steigerwald F, Utvik JK, Ottersen OP, Köhr G, D’Angelo E (2002) Cerebellar synaptic excitation and plasticity require proper NMDA receptor positioning and density in granule cells. J Neurosci 22:9687-9697. 
Rumbaugh G, Vicini S (1999) Distinct synaptic and extrasynaptic NMDA receptors in developing cerebellar granule neurons. J Neurosci 15:10603-10610.

Sakaguchi S, Katamine S, Nishida N, Moriuchi R, Shigematsu K, Sugimoto T, Nakatani A, Kataoka Y, Houtani T, Shirabe S, Okada H, Hasegawa S, Miyamoto T, Noda T (1996) Loss of cerebellar Purkinje cells in aged mice homozygous for a disrupted PrP gene. Nature 380:528-531.

Salès N, Hässig R, Rodolfo K, Di Giamberardino L, Traiffort E, Ruat M, Frétier P, Moya KL (2002) Developmental expression of the cellular prion protein in elongating axons. Eur J Neurosci 15:1163-1177.

Shmerling D, Hegyi I, Fischer M, Blättler T, Brandner S, Götz J, Rülicke T, Flechsig E, Cozzio A, von Mering C, Hangartner C, Aguzzi A, Weissmann C (1998) Expression of amino-terminally truncated PrP in the mouse leading to ataxia and specific cerebellar lesions. Cell 93:203-214.

Silver RA, Cull-Candy SG, Takahashi T (1996) Non-NMDA glutamate re- ceptor occupancy and open probability at a rat cerebellar synapse with single and multiple releases sites. J Physiol 494:231-250.

Sola E, Prestori F, Rossi P, Taglietti V, D’Angelo E (2004) Increased neurotransmitter release during long-term potentiation at mossy fibre-granule cell synapses in rat cerebellum. J Physiol 557:843-861.

Steele AD, Emsley JG, Ozdinler PH, Lindquist S, Macklis JD (2006) Prion protein $\left(\operatorname{PrP}^{\mathrm{c}}\right)$ positively regulates neural precursor proliferation during developmental and adult mammalian neurogenesis. Proc Natl Acad Sci U S A 103:3416-3421.

Wall MJ, Robert A, Howe JR, Usowicz MM (2002) The speeding of EPSC kinetics during maturation of a central synapse. Eur J Neurosci 15:785-797.

Walz R, Castro RM, Velasco TR, Carlotti CG Jr, Sakamoto AC, Brentani RR, Martins VR (2002) Cellular prion protein: implications in seizures and epilepsy. Cell Mol Neurobiol 22:249-257. 